\title{
Ecophysiological model of growth and reproduction of the black pearl oyster, Pinctada margaritifera: potential applications for pearl farming in French Polynesia
}

\author{
Stéphane Pouvreau ${ }^{\mathrm{a}, \mathrm{b}}$, Cédric Bacher $^{\mathrm{a}}$ and Maurice Héral ${ }^{\mathrm{a}}$ \\ a : CREMA (IFREMER-CNRS), BP 5, 17137, L'Houmeau, France \\ b : IFREMER COP, BP 7004, Taravao, Tahiti, French Polynesia \\ *: Corresponding author : Tel. : 335465094 40; Fax: 335465006 00; E-mail : spouvrea@ifremer.fr
}

\begin{abstract}
:
A model of bioenergetics of the black pearl oyster (Pinctada margaritifera) was built to simulate growth, reproduction and spawning in suspended culture at field sites in Takapoto lagoon (French Polynesia). This model was based on allometric scaling of physiological functions and scope for growth (SFG) calculations. The input functions were clearance rate $\left(\mathrm{CR}, \mathrm{I}\right.$ day $\left.^{-1}\right)$, retention efficiency $(\mathrm{RE}, \%)$ for each kind of particle encountered in suspended matter, pseudofaeces and faeces productions ( $P F$ and $F, m g C$ day $\left.^{-1}\right)$, excretion and respiration rate $\left(U\right.$ and $R, m g C$ day $\left.^{-1}\right)$. The assimilated carbon (i.e., SFG, mg C day $^{-1}$ ) was partitioned to the three internal state variables (somatic tissue, shell and gonad) according to the asymptotic increase of the reproductive effort (ER, $\%)$ with the age. Given organic and mineral particulate matter in suspension in lagoon water (POM and PIM, $\mathrm{mg} \mathrm{L}^{-1}$ ) and assuming that the taxonomic composition of POM was fairly constant throughout the year, the model predicted annual evolution of total tissue weight ( $W_{\text {Tissue }}, g$ dry weight), shell weight $\left(W_{\text {Shell }}, g \mathrm{DW}\right)$ and gonad weight $\left(W_{\text {Gonad }}, \mathrm{g} \mathrm{DW}\right)$ of pearl oysters at various ages. Data on tissue and shell growth, but also on gonad development of cultivated pearl oysters, acquired in 19971998 in Takapoto lagoon, were used to validate the model outputs. Results of the simulations indicated that the P. margaritifera growth model provided realistic growth trajectories for shell, somatic tissue and gonad, for pearl oysters aged from 1 to 4 years.
\end{abstract}

For scientists, this validated model is very useful to understand more extensively feeding processes and reproduction features of $P$. margaritifera in Polynesian lagoons. It provides also valuable information for pearl farmers and for management of cultured populations, especially concerning the time to produce a pearl, spat collection, density in system culture, choice of farming site and carrying capacity of the whole lagoon. In this respect, the model demonstrates that local overdensity must be avoided especially when water current is low $\left(<1 \mathrm{~cm} \mathrm{~s}^{-1}\right)$ and that global consumption of the cultivated pearl oyster stocks plays a insignificant role in comparison with the consumption of all the natural bivalves occurring in the lagoon.

Nevertheless, this first growth model developed for $P$. margaritifera was only validated for a Takapoto atoll and presents several limitations concerning especially the temperature effect and the range of food concentration. Consequently, some improvements will be necessary to apply this work to other pearl farming sites in French Polynesia. 


\section{Abstract}

A model of bioenergetics of the black pearl oyster (Pinctada margaritifera) was built to simulate growth, reproduction and spawning in suspended culture at field sites in Takapoto lagoon (French Polynesia). This model was based on allometric scaling of physiological functions and Scope for Growth (SFG) calculations. The input functions were clearance rate $\left(\mathrm{CR}, \mathrm{l} \mathrm{d}^{-1}\right)$, retention efficiency (RE, \%) for each kind of particle encountered in suspended matter, pseudofaeces and faeces productions ( $\mathrm{PF}$ and $\mathrm{F}, \mathrm{mg} \mathrm{C}^{-1}$ ), excretion and respiration rate (U and $\mathrm{R}, \mathrm{mg} \mathrm{C} \mathrm{d}^{-1}$ ). The assimilated carbon (i.e. SFG, $\mathrm{mg} \mathrm{C} \mathrm{d}^{-1}$ ) was partitioned to the three internal state variables (somatic tissue, shell and gonad) according to the asymptotic increase of the reproductive effort (ER, \%) with the age. Given organic and mineral particulate matter in suspension in lagoon water (POM and PIM, mg $\mathrm{l}^{-1}$ ) and assuming that the taxonomic composition of POM was fairly constant throughout the year, the model predicted annual evolution of total tissue weight ( $\mathrm{W}_{\text {Tissue }}$, g dry weight), shell weight $\left(\mathrm{W}_{\text {Shell }}\right.$, $\left.\mathrm{g} \mathrm{DW}\right)$ and gonad weight ( $\mathrm{W}_{\text {Gonad, }}$ g DW) of pearl oysters at various ages. Data on tissue and shell growth but also on gonad development of cultivated pearl oysters, acquired in 1997-98 in Takapoto lagoon, were used to ground truth the model outputs. Results of the simulations indicated that the P. margaritifera growth model provided realistic growth trajectories for shell, somatic tissue and gonad, for pearl oysters aged from 1 year to 4 years.

For scientists, this validated model was very useful to understand more extensively feeding processes and reproduction features of $P$. margaritifera in Polynesian lagoons. It provides also valuable information for pearl farmers and for management of cultured populations, especially concerning the time to produce a pearl, spat collection, density in system culture, choice of farming site and carrying capacity of the whole lagoon. In this respect, the model demonstrates that local over-density must be avoided especially when water current is low $(<1$ $\mathrm{cm} \mathrm{s}^{-1}$ ) and that global consumption of the cultivated pearl oyster stocks plays an insignificant role in comparison with the consumption of all the natural bivalves occurring in the lagoon.

Nevertheless, this first growth model developed for P. margaritifera was only validated on Takapoto atoll and presents several limitations concerning especially the temperature effect and the range of food concentration. Consequently, some improvements would be necessary to generalise this work on other pearl farming sites of French Polynesia.

Key words : Tropical lagoon - Suspension feeding - Carrying capacity - Scope for growth - Food depletion Pearl farming. 


\section{INTRODUCTION}

In French Polynesia, black pearl aquaculture has played an increasing role since 1980. Today, production is approaching six metric tons of pearls (i.e. 160 millions of US dollars). After the large scale mortality which decimated cultivated pearl oysters, Pinctada margaritifera, in several atolls in 1985, French Polynesian authorities decided to set up a general research programme on the pearl oyster (PGRN). The main objective of PGRN was to assess the carrying capacity of a lagoon for pearl oyster farming, by taking Takapoto lagoon (Tuamotu archipelago, French Polynesia) as a study site.

Although the black pearl oyster was naturally one of the most abundant bivalves in the benthic fauna of Polynesian atoll lagoons, the development of pearl culture moved these benthic bivalves progressively into the pelagic environment, since farmers suspend pearl oysters on long-lines in mid-water. Thus, understanding the relationships between cultivated pearl oyster and pelagic food web is essential to study the carrying capacity of a given lagoon. To reach this aim, a first step is to build a deterministic ecophysiological model for cultivated pearl oysters in lagoon environment, explaining individual growth over several years, as a function of food availability and composition. Such a model is very useful since it provides validated bivalve requirements which are necessary in carrying capacity calculations.

Physiological models explaining the growth of cultivated molluscs in their environment in relation to food supplies have already been achieved on numerous bivalves species (e.g. Bacher et al., 1991; Powell et al., 1992; Schneider, 1992; Raillard et al., 1993; Van Haren and Kooijman, 1993; Barillé et al., 1997; Grant and Bacher, 1998; Scholten and Smaal, 1998). Generally, these models are based on the Scope for Growth concept and use a complete sequence of steps in nutrition and resources allocation.

This approach is applied here for the first time on P. margaritifera. In this respect, all the feeding processes previously studied in Polynesia (Robert et al., 1998; Pouvreau, 1999; Pouvreau et al., 1999a,b) were integrated in the present model. Furthermore, since adult pearl oysters are able to spawn several times a year (Thielley, 1993; Buestel et al., 1995; Pouvreau, 1999), reproductive effort was also incorporated in this growth model.

First, this study presents a global dynamic carbon model explaining individual growth and reproduction of $P$. margaritifera in a lagoon environment (Takapoto lagoon) over several years, as a function of food availability and composition. In order to validate the model, simulations of growth and reproduction were systematically tested against measurements. 
Second, applications of the validated model for pearl farming in Polynesia are also presented. Information of potential interest for pearl farmers is given, especially concerning spat collection and rate of nacreous deposition. Carrying capacity of Polynesian pearl farming sites is also approached : (1) at local scale (i.e. the system culture), we tested potential effect of density (POM-depletion) on the growth of pearl oyster ; (2) at a global scale (i.e. the whole lagoon), we computed, on the basis of model calculations, the clearance time of the cultivated and natural bivalve populations (Dame and Prins, 1998).

\section{MATERIALS AND METHODS}

\subsection{Model design and states variables}

Several simplifications were made to streamline the model for which a conceptual design is described on Fig. 1. The model uses a balanced carbon budget approach to simulate separately growth in shell and growth in total soft tissue including gonad. This model is based on (1) the widely applied (reviewed in Bayne, 1998; Hawkins et al., 1998a) Scope for Growth (SFG) concept (Bayne, 1976); (2) allometric relations between physiological functions and dry tissue weight ( $\mathrm{W}_{\text {Tissue) }}$. The SFG concept, already used in many models (e.g. Bacher et al., 1991; Schneider, 1992; Raillard et al. 1993; Barillé et al., 1997), assumes that energy or matter gained by food acquisition is equal to the energy or matter lost for maintenance, growth and reproduction. In this work, SFG is calculated as the difference between carbon acquired by feeding processes and lost by respiration (supposedly a measure of maintenance) and excretion for one individual, as follows :

$$
\begin{aligned}
& \mathrm{SFG}=\mathrm{FR}-(\mathrm{PF}+\mathrm{F}+\mathrm{R}+\mathrm{U}) \text {, where } \\
& \mathrm{SFG}=\text { scope for growth }\left(\mathrm{mg} \mathrm{C}^{-1} \mathrm{ind}^{-1}\right) \\
& \left.\mathrm{FR}=\text { consumption (retained organic matter, } \mathrm{mg} \mathrm{C} \mathrm{d}^{-1} \mathrm{ind}^{-1}\right) \\
& \mathrm{PF}, \mathrm{F}=\text { pseudofaeces and faeces production }\left(\mathrm{mg} \mathrm{C} \mathrm{d}^{-1} \mathrm{ind}^{-1}\right) \\
& \mathrm{R}=\text { respiration }\left(\mathrm{mg} \mathrm{O}_{2} \mathrm{~d}^{-1} \text {, converted in } \mathrm{mg} \mathrm{d}^{-1} \mathrm{ind}^{-1}\right) \\
& \left.\mathrm{U}=\text { urea and amino acid excretion (converted in } \mathrm{mg} \mathrm{C} \mathrm{d}^{-1} \mathrm{ind}^{-1}\right)
\end{aligned}
$$

If $\mathrm{SFG}>0$, carbon is partitioned into shell, soma and gonad (Resources allocation). If more carbon is required for maintenance (Respiration) than available from food (Assimilation), SFG becomes negative and carbon is mobilised firstly from gonad (utilisation of energy reserves). Therefore, states variables of the model were : (1) shell, (2) somatic tissue and (3) gonadal tissue. Shell represents the organic matrix. Somatic tissue includes gill, mantle, muscles and digestive gland (+viscera). Gonadal tissue includes developing and mature gametes.

\subsection{Environmental factors}

Temperature in this tropical environment, and especially in Takapoto lagoon, does not present great seasonal variations (from 26 to $30^{\circ} \mathrm{C}$ during "normal year", i.e. without El Niño event), so that temperature effect on pearl 
oyster physiology has not yet been demonstrated (Robert et al., 1998; Pouvreau et al., 1999b) and, consequently, was not included in the present model (this first limitation is analysed in discussion part). Alternatively, forcing functions in the model were pelagic food concentration and composition in Takapoto lagoon water. Potential food for pearl oysters was expressed as total particulate matter (TPM, mg $\mathrm{l}^{-1}$ ), and consisted of particulate inorganic matter (PIM, $\mathrm{mg} \mathrm{l}^{-1}$ ) and particulate organic matter (POM, $\mathrm{mg} \mathrm{l}^{-1}$ ). PIM and POM were monitored once a week from March 1997 to March 1998, always at the same hour (14:00, Fig. 2). This sampling hour generally corresponds to the daily maximum of seston concentration whereas minimum values were generally reached around 6:00 (Charpy, 1996; Buestel and Pouvreau, 2000). In order to take into account these night and day variations and avoid over-estimation of the daily mean, PIM and POM measured at 14:00 were corrected by 0.7. This value was obtained previously on the basis of several night and day measurements. Afterwards, POM was converted into carbon (POC, $\mathrm{mgC} \mathrm{l}^{-1}$ ) by using a conversion factor (POM/POC=2, Mann, 1979 for bivalve flesh; Parsons et al., 1961 for algae composition; Quemeneur and Marty, 1992 and Galois et al., 1996 for total suspended matter).

In P. margaritifera, retention efficiency is nearly null for $1 \mu \mathrm{m}$ particles and becomes maximal for $>5 \mu \mathrm{m}$ particles (Pouvreau et al., 1999a; Yukihira et al., 1999). Therefore, a part of POM cannot be directly retained on P. margaritifera gill. In this respect, POM in Polynesian lagoon need to be reviewed (Table 1) so that our model uses POM according to its size as input for consumption. Suspended matter is generally composed of a living (bacteria, phytoplankton, protozoan and zooplankton) and detritus material. In lagoonal waters, free bacteria were the smallest living particles $(0.4 \mu \mathrm{m})$. A part of them are fixed on larger particles but scarce data (Torréton and Dufour, 1996) are not sufficient to establish an order of magnitude. Phytoplankton is divided into two groups: (1) picophytoplankton $(<2 \mu \mathrm{m})$ which includes prokaryotic cyanobacteria (Synechococcus sp. and Prochlorococcus sp.) and eukaryotic algae (picoeukaryotes, Charpy and Blanchot, 1998), and (2) phytoplankton, which includes nano and micro-algae. Detritus is also divided into two groups : (1) pico-detritus $(<2 \mu \mathrm{m})$, and (2) larger detritus called micro-detritus. Protozoa are mainly heterotrophic nano- and micro-plankton and include ciliates, heterotrophic flagellates and dinoflagellates, foraminifers and radiolarians. Zooplankton consists mainly of micro-plankton and includes especially appendiculates and larvae of various species (naupliar copepods and bivalves, crustaceans and polychaetes larvae). Particulate matter $>200 \mu \mathrm{m}$ (mesoplankton) are not taken into consideration in this work because of their probable low representation in the diet of the bivalves. The contribution of each of these previous components to the total particulate organic matter was assumed to be 
fairly constant (trophic web in equilibrium, suggested by the low standard deviation in Table 1) and was estimated on the basis of the review described in Table 1.

\subsection{Physiological mechanisms formulations}

Each term presented in the SFG equation (see previous paragraph) was computed as a function of the forcing variables (exogenous factors) or/and the dry tissue weight, $\mathrm{W}_{\text {Tissue }}$ (endogenous factor). The physiological functions were studied extensively in previous works (Robert et al., 1998; Pouvreau, 1999; Pouvreau et al., 1999a,b) and the useful equations are summarised in Table 2. In the following paragraphs, we remind only what it is necessary to understand the model conceptualisation.

\subsubsection{Food acquisition}

Pearl oysters obtain their food by processing large amount of waters thanks to a high clearance capacity (Pouvreau et al., 1998 and 1999a for Polynesian water, Yukihira et al., 1998a for Australian water; and Hawkins et al., 1998b for Malaysian water). Using biodeposition method (Iglesias et al., 1998), the clearance rate CR (l $\mathrm{d}^{-}$ ${ }^{1}$ ) was estimated in situ on 196 oysters of various sizes under several natural seston load conditions, and varied according to the PIM and POM concentration as an allometric function of dry tissue weight $\mathrm{W}_{\text {Tissue }}$ (g), as follows (Pouvreau et al., 1999b):

$$
\mathrm{CR}=647.04( \pm 60.48 \mathrm{SE}) \bullet \mathrm{PIM}^{-0.42( \pm 0.05 \mathrm{SE})} \bullet \mathrm{POM}^{0.96( \pm 0.11 \mathrm{SE})} \bullet \mathrm{W}_{\text {Tissue }}{ }^{0.61( \pm 0.04 \mathrm{SE})} ;\left(\mathrm{n}=196, \mathrm{R}^{2}=0.75, \mathrm{P}<0.05\right)
$$

The well-developed gill of pearl oysters can efficiently retain particles $>2 \mu \mathrm{m}$ (Pouvreau et al., 1999a ; Yukihira et al., 1999). So each of the previous compartments in seston is retained differently according to its approximate mean size Sz ( $\mu$ m, equivalent spherical diameter) and according to the retention spectrum RE (\%) given by Pouvreau et al. (1999a), which exhibits the following logistic pattern :

$$
\mathbf{R E}=\mathbf{1 0 0} /\left(\mathbf{1}+\mathbf{5 2 . 1 6} \cdot \mathbf{0 . 1 3 7 ^ { \mathrm { Sz } }}\right) ;\left(\mathrm{n}=16, \mathrm{R}^{2}=0.86, \mathrm{P}<0.05\right)
$$

Mean size of bacteria, cyanobacteria, pico-detritus, picoeukaryotes was assumed to be approximately equal in mean to $0.4,0.8,1$ and $1.2 \mu \mathrm{m}$, respectively, giving a retention efficiency equal to 2, 6, 12 and $15 \%$, respectively, for these pico-particles $(<2 \mu \mathrm{m})$. Micro-particles $(>2 \mu \mathrm{m})$ were supposed to be retained in mean at $60 \%$. Then, the amount of retained organic matter, $\mathrm{FR}_{\mathrm{POM}}\left(\mathrm{mg} \mathrm{C} \mathrm{d}^{-1} \mathrm{ind}^{-1}\right)$ was computed as follows :

$$
\mathrm{FR}_{\mathrm{POM}}=\mathrm{CR} \cdot\left[0.02 \mathrm{POC}_{\text {bacteria }}+0.06 \mathrm{POC}_{\text {cyanobacteria }}+0.12 \mathrm{POC}_{\text {picodetritus }}+0.15 \mathrm{POC}_{\text {picoeukaryotes }}+0.6 \mathrm{POC}_{\text {microparticules }}\right]
$$




\subsubsection{Biodeposition}

Prior to ingestion, particles with low organic content are generally rejected in pseudofaeces. In P. margaritifera,

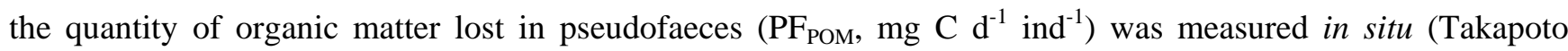
lagoon) and varied according to POM, PIM and $\mathrm{W}_{\text {Tissue, }}$ as follows (Pouvreau et al., 1999b):

$$
\left.\mathrm{PF}_{\text {POM }}=32.16 \text { ( } \pm 2.16 \mathrm{SE}\right) \bullet \mathrm{POM}[\mathrm{PIM}-0.18( \pm 0.02 \mathrm{SE})] \bullet \mathrm{W}_{\text {Tissue }} ;\left(\mathrm{n}=196, \mathrm{R}^{2}=0.69, \mathrm{P}<0.05\right)
$$

For PIM $<0.18 \mathrm{mg} \mathrm{l}^{-1}$, there is no pseudofaeces production. This minimum PIM-concentration is called the pseudofaeces production threshold.

The remaining organic material $\left(\mathrm{FR}_{\mathrm{POM}}-\mathrm{PF}_{\mathrm{POM}}\right)$ is ingested. A great part of the ingested organic matter is absorbed during intestinal transit. The non-absorbed organic material is ejected in faeces. Mineral matter is assumed to be not at all absorbed. In P. margaritifera, the organic faeces production $\left(\mathrm{F}_{\mathrm{POM}}, \mathrm{mg} \mathrm{C}^{-1}\right.$ ind $\left.^{-1}\right)$ was measured in situ for various seston load and composition and followed the equation (Pouvreau et al., 1999b):

$$
\mathrm{F}_{\mathrm{POM}}=\mathbf{4 8 0 . 0 0} \bullet \mathrm{W}^{0.49( \pm 0.72 \mathrm{SE})} \bullet\left(\mathbf{1}-\mathrm{e}^{-\mathbf{0 . 6 6}( \pm 0.06 \mathrm{SE}) \cdot \mathrm{TPM}}\right) ;\left(\mathrm{n}=196, \mathrm{R}^{2}=0.66, \mathrm{P}<0.05\right)
$$

\subsubsection{Oxygen consumption and excretion}

Routine oxygen consumption (Bayne, 1976) was monitored in situ (Takapoto lagoon) on various sizes of animal and at different seasons (Robert et al., 1998). This routine respiration rate represented in fact the metabolic requirements, i.e. routine metabolism and overheads for growth (soma and shell matrix) and also for reproduction, since a pearl oyster is more or less always in gametogenesis. These authors showed that respiration $\mathrm{R}$ (converted in $\mathrm{mg} \mathrm{C} \mathrm{d}^{-1}$ ) varied mainly according to $\mathrm{W}_{\text {Tissue, }}$ as follows (Robert et al., 1998) :

$$
\mathbf{R}=7.38( \pm 1.20 \mathrm{SE}) \bullet \mathbf{R Q} \bullet \mathrm{W}_{\text {Tissue }}{ }^{0.73( \pm 0.004 \mathrm{SE})} ;\left(\mathrm{n}=113, \mathrm{R}^{2}=0.76, \mathrm{P}<0.05\right)
$$

Knowing the proximal composition of the diet of pearl oysters in Takapoto lagoon (proteins $=0.5$, carbohydrates $=0.25$ and lipids $=0.25$, Buestel and Pouvreau, 2000), it was possible to estimate the respiratory coefficient, RQ, i.e. moles of $\mathrm{CO}_{2}$ liberated per mole of $\mathrm{O}_{2}$ consumed (\%), according to Gnaiger (1983). RQ was equal to 0.92, falling in the range given by Hawkins and Bayne (1985). Anaerobic metabolism is supposed to be insignificant since oysters are never emersed in the lagoon environment and oxygen is always in over-saturation in Takapoto lagoon (Haumani Gaby, Pers. comm.).

Excretion rate, $\mathrm{U}$ (converted in $\mathrm{mg} \mathrm{C} \mathrm{d}^{-1}$ ), was measured under laboratory conditions (Méro, 1996; Pouvreau et al., 1998) which simulated those of the lagoon environment. Carbon losses appeared when urea and amino acids 
were excreted. Urea and amino acids represented less than $10 \%$ of the total ammonia excreted, and increased with dry tissue weight, as follows :

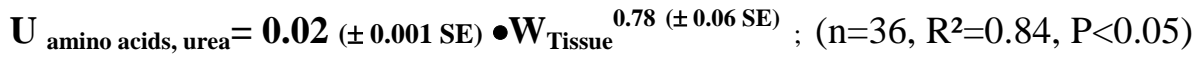

\subsubsection{Resources allocation to growth and reproduction}

Rules specifying the animal priorities for resources partitioning are not well-known. Different prior assumptions have been made concerning energy allocation between shell growth, tissue growth and reproductive outputs (Ross and Nisbet, 1990; Van Haren and Kooijman, 1993). For this model, we assume the two following rules :

(1) If absorbed carbon exceeds uptake for maintenance (Respiration) and losses in excreted urea and amino acids, the scope for growth (SFG, $\mathrm{mgC} \mathrm{h}^{-1}$ ) is positive and this surplus is partitioned into shell matrix, somatic and gonadal compartments. Dry shell, tissue and gonad weight $\left(\mathrm{W}_{\text {shell }}, \mathrm{W}_{\text {tissue }}\right.$, and $\left.\mathrm{W}_{\text {gonad }}\right)$ are, then, calculated from their respective carbon input and ash ratio ( $\mathrm{Ash}_{\text {Shell, }} \mathrm{Ash}_{\text {Tissue }}$ and $\left.\mathrm{Ash}_{\mathrm{Gonad}}\right)$. Allocation to gonad, i.e. reproductive effort (ER), increases with age (e.g. Bayne and Worrall, 1980; Thompson, 1984; Rodhouse et al., 1984). Considering that ER was approximately equal to 0, 9, 22 and $35 \%$ for pearl oysters of year class 0, 1, 2 and 3, respectively, (experimental data, Pouvreau, 1999), a classical logistic pattern according to the age was proposed here (see Table 2) to model ER. For the present, we make no difference between ER for males and ER for females, since during the 4 first years of life, cultivated pearl oyster are mainly males. The sex inversion causes probably physiological transformation, but we have not enough data to model this aspect. Part of carbon, which is not driven to gonad, i.e. (1-ER), is allocated to soma and shell matrix. Shell growth is proportional to somatic growth with a constant allocation to shell (Alloc Shell $_{1}=0.6$, Pouvreau, 1999) and to soma (1-Alloc shell $_{\text {). }}$

(2) When respiratory requirements and excretory losses exceed available absorbed carbon, SFG becomes negative and carbon is mobilised from gonad tissue, playing a kind of storage role. In fact, storage is virtually non-existent in this tropical bivalve (Buestel et al., 1995). So that, as soon as the food supply is sufficient, gonad development commences. Such an opportunistic strategy reproduction differs from the conservative strategy in many temperate bivalves, for which reserves are accumulated before gametogenesis. Validity of the model (accordance between simulation and observation) will imply that assumptions (1) and (2) are reasonably reliable.

\subsubsection{Gametes release}

Those (Thielley, 1993; Buestel et al., 1995; Pouvreau, 1999) who have worked on reproduction of this species in Polynesian lagoons have come to the same conclusion : pearl oysters are able to spawn several times and 
throughout the year. When food is sufficient for several weeks (i.e. POM x Days), the gonad expands due to gametogenesis. Various stressful exogenous factors (e.g. change in temperature, in salinity, in atmospheric pressure) are supposed to constitute spawning cues. Nevertheless, endogenous factors can also be involved : in this first model, gamete release, which is supposed to be complete and instantaneous, occurs when gonadosomatic ratio exceed a maximal value $\left(\mathrm{RGS}_{\max }>0.29\right.$, Pouvreau, 1999).

\subsubsection{Shell and pearl formation}

Dry shell weight ( $\left.\mathrm{W}_{\text {Shell }}\right)$ is used to compute the shell height $\left(\mathrm{H}_{\text {Shell, }}\right.$ Dorso-ventral axis, $\left.\mathrm{mm}\right)$ and the shell thickness ( $\mathrm{T}_{\text {Shell }}$, Hinge line, $\mathrm{mm}$ ) according to the specific allometric relationships (Table 2 and Pouvreau, 1999). Assuming that nacreous deposition on shell by mantle activity exhibits the same rate as nacreous deposition on the nucleus implanted in gonad diverticula, time of pearl formation, $\mathrm{t}_{\text {end }}$, can be calculated from the integral function :

$$
\begin{aligned}
& \mathbf{T}_{\text {Pearl }}=\int_{\boldsymbol{t}_{\mathrm{o}}}^{\boldsymbol{t}_{\text {end }}} \frac{\boldsymbol{d} \boldsymbol{T}_{\text {Shell }}}{\boldsymbol{d t}} \text {, where } \\
& \mathrm{T}_{\text {pearl }}=\text { Thickness of the nacreous layer for a marketable pearl }\left(\mathrm{T}_{\text {pearl }}=1.2 \mathrm{~mm}\right) \\
& \mathrm{t}_{\text {end }}=\text { Time to obtain a marketable pearl. }
\end{aligned}
$$

\subsubsection{Depletion calculation}

The filtration activity of dense aggregations of bivalves could locally deplete seston in water (Fréchette et al., 1989) especially if the currents that supply seston are too low to replenish completely the ingested particles. Since (1) P. margaritifera exhibits high clearance activity, (2) lagoon currents are generally low and (3) food supply is limited, depletion conditions can occur in culture system according to density and flow velocity (Fig. $3)$.

The seston concentration $\operatorname{POM}(x)$ within a culture of suspended bivalves is determined as a balance between the transport of particles from remote sources (flow velocity, U), the local production of new particles (primary production, PP), and the removal of particles due to feeding of bivalves populations (density.consumption, d.FR $\mathrm{POM}_{\text {) }}$ or sinking (sinking rate, SR) :

$$
\frac{\partial \mathbf{P O M}}{\partial \mathrm{t}}=-\mathbf{U} \cdot \frac{\partial \mathbf{P O M}}{\partial \mathbf{x}}+\mathbf{P P}-\text { d.CR.POM - SR }
$$


Two assumptions were made to simplify calculations : (1) the local production and the sinking rate are negligible in comparison with transport $\left(\mathrm{PP}<<\mathrm{U} \bullet \frac{\partial \mathrm{POM}}{\partial \mathrm{x}}\right.$ and $\left.\mathrm{SR}<<\mathrm{U} \bullet \frac{\partial \mathrm{POM}}{\partial \mathrm{x}}\right)$; (2) the system is in steady state $\left(\frac{\partial \mathrm{POM}}{\partial \mathrm{t}}=0\right)$. With such assumptions, depletion ratio after i long line systems, $\mathrm{D}_{\mathrm{i}}$, , i.e. (POM after i long lines)/(POM entered the system), is equal to :

$$
\begin{aligned}
& \qquad \mathbf{D}_{\mathbf{i}}=\mathbf{e}^{-\frac{\mathbf{d} . \mathbf{C R} . \mathbf{i}}{\mathbf{U}}} \text {, where } \\
& \mathrm{D}_{\mathrm{i}}=\text { depletion ratio after i long lines } \\
& \left.\mathrm{d}=\text { linear density on long lines (ind. } \mathrm{m}^{-1}\right) \\
& \mathrm{CR}=\text { clearance rate of pearl oysters (converted } \mathrm{in}^{3} \mathrm{~s}^{-1} \text { ) } \\
& \mathrm{i}=\text { number of juxtaposed long lines } \\
& \mathrm{U}=\text { flow velocity }\left(\mathrm{m} \mathrm{s}^{-1}\right)
\end{aligned}
$$

\subsection{Simulations and validation}

The model was implemented in STELLA software (High Performance Systems, Hannover, NH, USA). List of equations, parameters and variables are presented in Table 2 and Table 3. Model results (predicted values) were compared to data on shell, soma and gonad growth of various age-groups of pearl oysters measured in 19971998 (observed values, Pouvreau et al., 2000). This allowed assessment of both the shape of the trajectory of total tissue and shell weight as well as the numerous peak weights observed for gonads. 


\section{RESULTS}

\subsection{Model evaluation and validation}

The growth of the pearl oysters is presented in Fig. 4 (a, b, c), expressed as total dry tissue weight ( $\left.\mathrm{W}_{\text {Tissue }}, \mathrm{g}\right)$, dry shell weight ( $\left.\mathrm{W}_{\text {Shell, }}, \mathrm{g}\right)$ and dry gonad weight $\left(\mathrm{W}_{\text {Gonad, }} \mathrm{g}\right)$, and compared with measured data of 1,2 and 3 year-old pearl oysters cultivated during the 1997-98 sampling period. The agreement between observed and predicted values was fairly good for shell, tissue and gonad $\left(\mathrm{R}^{2}=0.99, \mathrm{R}^{2}=0.98\right.$ and $\mathrm{R}^{2}=0.92$ respectively, Fig. 4 d, e, f). Shell growth was completely explained as well as gonad development. Modelled total tissue growth appeared to closely follow observed tissue growth except during the warmer month (December-March) when the model had a tendency to overestimate somatic growth and during the fresher month (June-September) during which the model showed a slight underestimation. Except for this last feature, the $P$. margaritifera growth model showed in general a fairly good reliability and predicted both growth and reproduction for cultivated pearl oysters from 1 to 4 year-old in Takapoto lagoon.

\subsection{Physiological processes}

Once the model is validated, assessment of the main physiological processes and their temporal variations were derived from the model (Fig. 5). In situ CR mean value varied roughly from 200 to more than $1500 \mathrm{l} \mathrm{d}^{-1}$ for a pearl oyster aged from 1 to 4 years (Fig. 5a). This high clearance activity brought to pearl oyster large amounts of food (Consumption, FR) averaging 20 and $80 \mathrm{mg} \mathrm{C} \mathrm{d}^{-1}$ according to the age of pearl oyster (Fig. 5b). High values of FR were encountered in December when POM load and seston composition were favourable, low values in July. A part of consumed matter was lost as pseudofaeces, which occurred all year (Fig. 5c) and varied from roughly 2 to $7 \mathrm{mg} \mathrm{C} \mathrm{d}^{-1}$. The highest values of organic PF were encountered when PIM was the highest (e.g. March-April). The other part was lost through faeces production (F) which varied in mean from 10 to more than $30 \mathrm{mg} \mathrm{C} \mathrm{d}^{-1}$ according to the age of pearl oyster (Fig. 5d). The amount of ingested matter which was really absorbed (absorption, $A_{b} R$, Fig. 5e) varied in mean from 15 to $35 \mathrm{mg} \mathrm{C} \mathrm{d}^{-1}$. Model calculated also scope for growth (SFG, Fig. 5f) : for most of the time, SFG was positive (from 10 to $30 \mathrm{mg} \mathrm{C} \mathrm{d}^{-1}$ with the age), allowing regular growth and gametogenesis.

\subsection{Productions}

Two productions were analysed further because of their potential interest for pearl oyster farming : (1) gonad development for spat collection, and (2) rate of nacreous deposition on shell and nuclei. 
Simulated annual evolution of the gonad was presented on Fig. 4C. In age-group 1, dry gonad weight increased during the year (acquisition of maturity) and a hypothetically spawning occurred in January 1998. In age-group 2, a large increase was observed during the first 6 months. Then, a spawning occurred in October, and again in January. In age-group 3, spawning was simulated in May, and again in October, December and in January. The model predicted no release during winter season. Furthermore during this last season, a decrease in gonad weight is simulated by the model. It appeared from model simulation that spat collection would be better in summer. The intensity (production of gametes, Pr) of each release was calculated by the model (Table 4). Pr was proportional to $\mathrm{W}_{\text {Tissue }}(\mathrm{g})$, according to linear equation :

$$
\operatorname{Pr}(\mathrm{g})=0.086 \mathrm{~W}_{\text {Tissue }}\left(\mathrm{R}^{2}=0.99, \mathrm{n}=7, \mathrm{P}<0.001\right)
$$

Gametes released by a 1 year-old pearl oyster seemed to be insignificant, however, a pearl oyster spawns in mean 100-200 mg in its second year, and more than $700 \mathrm{mg}$ in its fourth year.

Shell formation (nacreous deposition and shell height increasing) was also simulated by the model. Fig. 6 shows that nacreous deposition and shell height increment varied according to food annual variations, but also according to the age of pearl oyster. The mean daily nacreous deposition was equal in mean to $7.1 \mu \mathrm{m} \mathrm{d}^{-1}$ ind $^{-1}$ for a 1 year-old pearl oyster. This value decreased to only $2.5 \mu \mathrm{m} \mathrm{d}^{-1}$ ind $^{-1}$ for 3 year-old pearl oysters. Since a black pearl must have a nacreous layer of at least $1 \mathrm{~mm}$ to be marketable, time to produce a pearl estimated by the model was roughly equal to 16 months in a 3 year-old pearl oyster. This simulated time is in total concordance with observed value (approx. 16-18 months). Since the mean daily nacreous deposition decreased with the age of pearl oyster, time to produce a pearl would be reduced in younger animals : 10 months for a 2 year-old pearl oyster and 6 months for a 1 year-old pearl oyster.

\subsection{Food supply and POM depletion}

Since concentration of POM is generally low (i.e. never in excess for P. margaritifera), a slight decrease would have a great impact on the growth and the reproduction of pearl oysters. With the help of the model, we tested the effect of POM decrease on growth. Fig. 7A shows that the decrease in tissue, gonad and shell weight becomes significant (>20\%) if level in POM is 20\% lower during one year. For $>30 \%$ POM reduction around the bivalve, the decrease in tissue and gonad weight is very important ( $>50 \%)$. Decrease in shell weight is less important since shell is assumed to be not resorbed, when SFG is negative.

Such a POM reduction was also tested, on a 3 year-old pearl oyster, on the time to produce a marketable pearl ( $\mathrm{t}_{\text {end }}$, in month) and on the number of gametes releases ( $\left.\mathrm{n}_{\text {gametes }}\right)$ by year (Fig. 7B). Both variables showed a high 
dependence to POM decrease. When POM is reduced by 10\%, the number of releases becomes equal to $3 \mathrm{y}^{-1}$ and time for pearl formation increases to 22 month (initial values were respectively equal to $4 \mathrm{y}^{-1}$ and 16 months). For $>20 \%$ POM decrease, $t_{\text {end }}$ reaches roughly 30 months and increases dramatically afterwards, while $\mathrm{n}_{\text {gametes }}$ becomes equal to $1 \mathrm{y}^{-1}$ for $20 \%$ POM reduction and null thereafter. Thus, a reduction of $20 \%$ of POM around the bivalve for protracted periods constitutes a limit which should not be exceeded.

There are several factors which may cause such a POM-reduction. Among these factors, filtration activity of dense aggregations of bivalves is well-known to locally deplete POM, especially when (1) water currents are low, (2) clearance rates of bivalves are high and (3) food supply is limited. Since culture of pearl oyster in lagoon environment generally meet these three conditions, we tested the cross-effect of both density in culture system and flow velocity on food depletion (Fig. 8). The culture system was assumed to be long-lines, and flow direction was set perpendicular to the long lines. In this case, POM depletion is largely insignificant $(<20 \%)$ if flow velocity is above $1 \mathrm{~cm} \mathrm{~s}^{-1}$. Alternatively, for flow velocities $<0.1 \mathrm{~cm} \mathrm{~s}^{-1}$, POM depletion becomes high (> $60 \%)$. For flow velocity comprised between $0.1 \mathrm{~cm} \mathrm{~s}^{-1}$ and $1 \mathrm{~cm} \mathrm{~s}^{-1}$, various cases are encountered according to the number of long-lines and the linear density (see Fig. 8). In a lagoon environment, current is often around 1 $\mathrm{cm} \mathrm{s}^{-1}$. Consequently, to avoid POM-depletion, linear density must be kept below 20 ind. $\mathrm{m}^{-1}$. 


\section{DISCUSSION}

\subsection{Model validation}

This growth model has the advantages of integrating all the existing knowledge acquired on P. margaritifera physiology in Takapoto atoll or in laboratory experiments close to Polynesian lagoonal conditions. Agreement between simulations and observations tends to demonstrate that (1) the input data concerning food were appropriate ; (2) the main physiological functions governing the bivalve were well-understood, and (3) model parameters estimation errors were presumably low.

Food sources : Firstly, this model demonstrated effectively that POM $>2 \mu \mathrm{m}$ (micro-algae, protozoan, microzooplankton and detritus) in suspension in Takapoto lagoon water was sufficient to explain observed growth rate. In that respect, the role played by picoplankton $(<2 \mu \mathrm{m}$, e.g. picoeukaryotes, cyanobacteria, bacteria and picodetritus) in the pearl oyster diet is directly insignificant, but may become indirectly significant if ingested by higher trophic levels (i.e. protozoan and micro-zooplankton, e.g. Le Gall et al., 1997; Dupuy et al., 1999) or incorporated with colloids in large structures (marine snow or aggregates). These assumptions firstly enounced in Pouvreau et al. (1999a) are clearly confirmed in a quantitative way by this model.

Physiological processes : The model supports our knowledge and assumptions on the physiology of $P$. margaritifera in its Polynesian lagoon environment. Clearance activity of P. margaritifera appeared effectively to be very high : simulated daily mean calculated over a period of one year was roughly equal to $1500 \mathrm{ld}^{-1}$ for adult oysters. This value is in total agreement with previous laboratory or field observations (Pouvreau et al., 1998; Yukihira et al., 1998a; Pouvreau et al., 1999a,b) and supports Jørgensen's (1990) assumption that the capacity for water processing in bivalves is an adaptation to the concentration of suspended food. Clearance activity was negatively related to PIM and positively related to POM concentration in the seston range commonly observed in Polynesian lagoon water i.e. TPM comprised between 0.6 and $1.3 \mathrm{mg} \mathrm{l}^{-1}$. It is reasonable to assume that under higher TPM (so higher PIM), the clearance capacity of P. margaritifera would decrease. Yukihira et al. (1998b) have shown that P. margaritifera reduces its clearance activity as seston load increases, but these authors fed pearl oysters with an algal diet under laboratory conditions and feeding behaviour in natural habitats may differ. Since various atolls (>80) exist in the Polynesian archipelago, various TPM concentrations may be encountered, and it would be useful to study in situ variations of $P$. margaritifera pumping or clearance rate for larger TPM range, in order to apply the growth model in other atoll lagoons. 
Losses of organic matter as PF was low in P. margaritifera since it represented less than $10 \%$ of the particulate carbon retained on gill. Nevertheless, TPM concentrations showed direct effects on pseudofaeces production, so that PF production would be further analysed under a wider range of natural seston load in order to test the ability of pearl oyster to live in more turbid waters as those encountered in lagoon of high island of Polynesia.

\subsection{Model uncertainty}

Despite the apparent reliability of the growth model, some differences remain between the model and the observed data and may reasonably be explained by several factors which were disregarded.

Food sources : First, the model attempts to incorporate, with different efficiencies, all kind of particles (living cells and detrital matter) which occur in the atoll lagoon mid-waters. Partitioning organic particles in various compartments according to their size and their trophic position was twofold : (1) pearl oysters differentially retain particles according to their size, so that POM cannot be totally incorporated as food for this bivalve; and (2) linking pearl oyster growth sub-model with trophic web model would be easier in further work.

Although a wide review has been made to ensure an accurate estimation of the mean POM taxonomic composition, in reality, suspended particles are much more complex since : (1) aggregates building was not taken into account and (2) food web was supposed to be always in equilibrium.

Less is known about aggregates especially in lagoon environment, but these particles are generally embedded in mucus to constitute large and fragile structure called "marine snow" (e.g. Marshall, 1968; Coles and Strathmann, 1973). Since the size of marine snow is $>1 \mu \mathrm{m}$, it would be efficiently retained on pearl oyster gills. However, these structures are fragile, so it is difficult to make assumptions. Further field experiments should focus on aggregates, their role in the pearl oyster diet and in the trophic web.

The second hypothesis, underlying the model inputs, was that the food web was in equilibrium, so that contribution of each compartment to the total POM-biomass was roughly constant all year round. Although this assumption was also the basis of the food web model proposed also for Takapoto lagoon by Niquil et al. (1998) and although seasonal variations are weak in this environment, further field experiments with an appropriately large sampling scheme should be conducted.

Physiological processes : Utilisation of food sources and translation to bivalve tissue involves several steps which were successively simplified to be modelled. These simplifications may violate some biological features, but simplifications are necessary to assist building and application of a model. 
A major source of uncertainty was related to the fact that the temperature is not incorporated in the present model. During "normal" annual cycle (without El Niño event), water temperature varied from 26 to $30^{\circ} \mathrm{C}$ (Pouvreau et al., 2000) and, in such a narrow range of variation, we did not succeed to demonstrate any effect of temperature on the physiology of P. margaritifera (Robert et al., 1998; Pouvreau 1999; Pouvreau et al., 1999b). Nevertheless, during El Niño year, water temperature may reach $31.5^{\circ} \mathrm{C}$ in Takapoto atoll. During such an event, temperature would have presumably significant physiological effects, especially on clearance activity and $\mathrm{O}_{2}$ consumption (e.g. Bougrier et al., 1995 ; Haure et al., 1998 for temperate species) but also on gametogenesis. Growth data, which were used to validate the model, were obtained during an El Niño year (1997-98). This feature probably explains the fact that the model slightly overestimated observed growth in warmer months. Incorporation of temperature will also be necessary to generalise the model to other pearl farming sites of French Polynesia for which temperature may vary from 22 to $32^{\circ} \mathrm{C}$ according to the latitude.

\subsection{Model predictions}

This growth model proposed for cultivated pearl oysters gave preliminary information relevant to pearl farming management and carrying capacity.

\subsubsection{Spat collection}

Temperature is commonly assumed as a determinant factor in maturation and gamete release. Our model suggests that, in a tropical environment with narrow range of temperature variation such as Takapoto atoll, POM be considered the main determinant factor. If temperature variations may act as a trigger for release, POM determines gametogenesis. In winter (June-September), spat settlement is generally not observed (Prou et al., 1999). Our model suggests that POM supplies are sufficient during winter months to ensure somatic growth, but insufficient to permit rapid gametogenesis. Alternatively, recruitment is generally observed several times between November and May (Prou et al., 1999), implying that several release events may occur in the warm season (Thielley, 1993; Buestel et al., 1995). This was predicted by our model (4 simulated releases in adult oysters between October and May) by considering only POM supplies. With further validation, it may be possible to predict peak recruitment periods and thus allow farmers to more effectively deploy collectors.

\subsubsection{Pearl formation}

The model assumes that the rate of nacreous deposition is the same on shell as it is on implanted nuclei. Such an assumption appears valid as the time to produce a marketable pearl simulated by the model was roughly the 
same as the time commonly observed in field (i.e. 16-18 months). Further, daily increments of nacreous deposition are in agreement of those found experimentally by Caseiro (1993). In this respect, the model showed that the rate of nacreous deposition is faster in young oysters. In fact, in young oysters ( $<2$ year-old), reproductive effort is low, so that nearly all the scope for growth is devoted to somatic and shell tissue. If these young oysters were able to be nuclei-implanted, the time to produce a marketable pearl would be reduced. However, young pearl oysters are generally too small to be easily implanted without damage. So, a compromise would be found between an oyster large enough to be implanted, but not too old to have a low increment rate : a 2 year-old pearl oyster ( $80 \mathrm{~mm}$ in height) would be the best compromise.

\subsubsection{Carrying capacity}

Carrying capacity can be approached at a local scale, i.e. density on long-lines and problem of food depletion, or/and at a global scale, i.e. total biomass in the whole lagoon and problem of overstocking.

On a local scale, model simulations showed that under low current conditions $\left(<1 \mathrm{~cm} \mathrm{~s}^{-1}\right)$, POM depletion might occur. If such conditions should remain for several weeks, a decrease of the growth would occur, especially in area where long-lines are dense. Rougerie (1979) measured effectively currents from 10 to less than $1 \mathrm{~cm} \mathrm{~s}^{-1}$ according to depth and wind conditions, so that POM-depletion may presumably occur. We have no other field data to support such results, but they will be checked in further field studies.

At a global scale, calculation of the total clearance time associated with primary production time (B/P, in days) would be a good indicator of occasional excess in stocks of bivalves. The clearance time (CT, in days) of a bivalve population is defined as "the time that is theoretically needed for the total bivalve filter feeder biomass within an ecosystem to filter particles from a volume of water equivalent to the total system volume” (Dame and Prins, 1998). Using stock assessments and model results on annual mean consumption of P. margaritifera, CT was calculated for cultivated pearl oysters but also for natural pearl oysters (Table 5) and extrapolated for other suspension feeding bivalves known in Takapoto lagoon assuming that cultivated pearl oyster and sessile bivalves feed with the same rate and on the same pool and size of material. If only cultivated pearl oysters were taken into account, the CT was very high, i.e. more than 1000 days, in comparison with primary production time (approx. 1 day). In that respect, cultivated pearl oysters would play an insignificant role in the global lagoon ecosystem. Alternatively, if all the potential trophic competitors (Addessi, 1997b), are taken into consideration, CT decreased to roughly 6 days, whereas production time is approx. equal to 1 day. 
This lagoon environment falls within the fast systems (short turnover times) according to Dame and Prins (1998), and fits well with their assumptions that fast system are generally smaller with denser populations of bivalves. This system differs strongly from Marennes-Oléron Bay (Héral, 1991), South San Fransisco bay or North Inlet where suspension feeders population are dominated by harvested bivalves, which act strongly on the system. In Takapoto lagoon, and presumably other Polynesian lagoons, suspension feeders are dominated by natural bivalves which play the major role in the system. From now, a global (and strongly simplified) vision of the trophic food web in a cultivated ecosystem as Takapoto lagoon can be proposed (Fig. 9). This preliminary scheme describes the previous conclusion, i.e. the insignificant role of the cultivated population in the whole system. Thus, for pearl farming management, it is evident that the exploited stock could be increased without damage provided long-lines systems are well spaced and the abundance of trophic competitors is taken into consideration.

\section{CONCLUSION}

Simulation of growth and reproduction for an individual pearl oyster under natural food gave realistic results over a period covering a complete rearing cycle. Thus, the model can be used as a useful tool in predicting growth, gametogenesis and pearl formation. Nevertheless, validation of this model in other lagoons devoted to pearl culture will be necessary. This model gives first indications of the carrying capacity on a local and global scale. Further works will focus on the interaction (i.e. feedback) between pearl oysters, pelagic food web and potential competitors in a more complex trophic web model. Validation of the density effect on food depletion around long-lines would also be necessary.

\section{Acknowledgements}

This work was carried out at in French Polynesia at the IFREMER Pacific Oceanological Centre and was supported by the General Research Program on Pearl Oyster ("Programme Général de Recherche sur la Nacre, deuxième phase, PGRN 2"). This program was founded by the French research ministry, the French overseas ministry, and the French Polynesia government. We would like to thank all the persons from the IFREMER pearl oyster laboratory and the SRM field station, and especially Dominique BUESTEL (IFREMER-Palavas, France) for having initiated this work. 


\section{REFERENCES}

Addessi, L., 1997a. Estimation des stocks de bivalves autres que la nacre dans l'atoll de Takapoto. Rapport PGRN, IFREMER Tahiti, 11 pp.

Addessi, L., 1997b. Ecophysiologie des principaux bivalves autres que la nacre et leurs interactions. Rapport PGRN, IFREMER Tahiti, 22 pp.

Bacher, C., Héral, M., Deslous-Paoli, J.M., Razet, D., 1991. Modèle énergétique uniboite de la croissance des huîtres (Crassostrea gigas) dans le bassin de Marennes-Oléron. Can. J. Fish. Aquat. Sci. 48, 391-404.

Barillé, L., Héral, M., Barillé-Boyer, A.L., 1997. Modélisation de l'écophysiologie de l’huître creuse Crassostrea gigas dans un environnement estuarien. Aquat. Living Resour. 10, 31-48

Bayne, B.L., 1976. Marine Mussels : Their Ecology and Physiology. Cambridge University Press, Cambridge, 506 pp.

Bayne, B.L., Worrall, C.M., 1980. Growth and production of mussels Mytilus edulis from two populations. Mar. Ecol. Prog. Ser. 3, 317-328.

Bayne, B.L., 1998. The physiology of suspension feeding by bivalve molluscs: an introduction to the Plymouth « TROPHEE » workshop. J. Exp. Mar. Biol. Ecol. 219, 1-19.

Blanchot, J., Charpy, L., Le Borgne, R., 1989. Size composition of particulate organic matter in the lagoon of Tikehau atoll (Tuamotu archipelago). Mar. Biol. 102, 329-339.

Bougrier, S., Geairon, P., Deslous-Paoli, J.M., Bacher, C., Jonquières, G., 1995. Allometric relationships and effects of temperature on clearance rate and oxygen consumption of Crassostrea gigas (Thunberg). Aquaculture, 134, 143-154.

Buestel D., Pouvreau S., 2000. Evolution spatio-temporelle de la matière en suspension, nourriture potentielle pour l'huître perlière Pinctada margaritifera, dans le lagon de Takapoto (Tuamotu, Polynésie Française). Oceanologica Acta, in press.

Buestel, D., Pouvreau, S., Tiapari, J., Bougrier, S., Chabirand, J.M., Geairon, P., Fougerouse, A., 1995. Ecophysiologie de l'huître perlière : Approche des relations entre la croissance de l'huitre Pinctada margaritifera et le milieu dans le lagon de Takapoto. Rapport IFREMER, RIDRV 95-18 RA, Tahiti, 79 pp.

Caseiro, J., 1993. L’huître perlière de Polynésie. Biominéralisation, Paramètres et processus de croissance, effets chromatiques dans la coquille et la perle de Pinctada margaritifera. Th. Univ. Claude Bernard, Lyon I, France, $\mathrm{N}^{\circ} 217-93,171 \mathrm{pp}$.

Charpy, L., 1996. Phytoplankton biomass and production in two Tuamotu atoll lagoons (French Polynesia). Mar. Ecol. Prog. Ser. 145, 133-142.

Charpy, L., Blanchot, J., 1998. Photosynthetic picoplankton in French Polynesian atoll lagoons : estimation of taxa contribution to biomass and production by flow cytometry. Mar. Ecol. Prog. Ser. 162, 51-70.

Charpy, L., Charpy-Roubaud, C.J., 1990. Trophic structure and productivity of the lagoonal communities of Tikehau atoll (Tuamotu Archipelago, French Polynesia). Hydrobiologia 207, 43-52.

Charpy L., Charpy-Roubaud, C.J., 1991. Particulate organic matter fluxes in a Tuamotu atoll lagoon (French Polynesia). Mar. Ecol. Prog. Ser. 71, 53-63.

Charpy, L., Blanchot, J., Lo, L., 1992. Contribution des cyanobactéries (Synechococcus spp) à la production phytoplanctonique dans un lagon d'atoll fermé (Takapoto Tuamotu Polynésie Française). CR Acad. Sc. Paris. Life Sci. 314 (3), 395-401.

Charpy, L., Buestel, D., Pouvreau, S., Cabral, P., 1994. Synthèse des recherches sur l'environnement du lagon de Takapoto. In : Résumé des actions de recherches du PGRN/ partie 1. Rapport PGRN, IFREMER-EVAAM, Tahiti. pp 1-51.

Charpy, L., Dufour, P., Garcia, N., 1997. Particulate organic matter in sixteen Tuamotu atoll lagoons (French 
polynesia). Mar. Ecol. Prog. Ser. 151, 55-65.

Coles, S.L., Strathmann, R., 1973. Observations on coral mucus «flocs » and their potential trophic significance. Limnol. Oceanogr. 18, 673-678.

Dame, R.F., Prins, T.C., 1998. Bivalve carrying capacity in coastal ecosystems. Aquat. Ecol. 31, 409-421.

Dufour, P., Torréton, J.P., 1996. Utilisation of bacterioplankton as a food source by the pearl oyster Pinctada margaritifera. In: Lessios H.A. (Ed), Proc. $8^{\text {th }}$ Int. Symp. Coral Reef, Panamà (Panama), Abstracts pp 54.

Dupuy, C., Le Gall, S., Hartmann, H.J., Breret, M., 1999. Retention by the oyster Crassostrea gigas of ciliates and flagellates from a natural community in Charente oyster ponds : protists as a trophic link between bacterioplankton and benthic suspension-feeders. Mar. Ecol. Prog. Ser. 177, 165-175.

Fréchette, M., Butman, C.A., Geyer, W.R., 1989. The importance of boundary-layer flows in supplying phytoplankton to the benthic suspension feeder Mytilus edulis L. Limnol. Oceanogr. 34, 19-36.

Galois, R., Richard, P., Fricourt, B., 1996. Seasonal variations in suspended particulate matter in the MarennesOléron Bay, France, using lipids as biomarkers. Est. Coast. Shelf Sci. 43, 335-357.

Gnaiger, E., 1983. Calculation of energetic and biochemical equivalents of respiratory oxygen consumption, Appendix C. in: Polarographic Oxygen Sensors, Aquatic and Physiological Application, Gnaiger E., Forstner, H. (Ed.). Springer-Verlag, Berlin, 370 pp.

Grant, J., Bacher, C., 1998. Comparative models of mussel bioenergetics and their validation at field culture sites. J. Exp. Mar. Biol. Ecol. 219, 21-44.

Haure, J., Penisson, C., Bougrier, S., Baud, J.P., 1998. Influence of temperature on clearance and oxygen consumption rates of the flat oyster Ostrea edulis : determination of allometric coefficients. Aquaculture 169, 211-224.

Hawkins, A.J.S., Bayne, B.L., 1985. Seasonal variation in the relative utilization of carbon and nitrogen by the mussel Mytilus edulis: budgets, conversion efficiencies and maintenance requirements. Mar. Ecol. Prog. Ser. 25, 181-188.

Hawkins, A.J.S., Bayne, B.L., Bougrier, S., Héral, M., Iglesias, J.I.P., Navarro, E., Smith, R.F.M., Urrutia, M.B., 1998a. Some general relationships in comparing the feeding physiology of suspension-feeding bivalve molluscs. J. Exp. Mar. Biol. Ecol. 219, 87-103.

Hawkins, A.J.S., Smith, R.F.M., Tan, S.H., Yasin, Z.B., 1998b. Suspension-feeding behaviour in tropical bivalve molluscs: Perna viridis, Crassostrea belcheri, Crassostrea iradelei, Saccostrea cucculata and Pinctada margaritifera. Mar. Ecol. Prog. Ser. 166, 173-185.

Héral, M., 1991. Approches de la capacité trophique des écosystèmes conchylicoles : synthèse bibliographique. ICES Mar. Sci. Symp. 192, 48-62.

Iglesias, J.I.P., Urrutia, M.B., Navarro, E., Ibarrola, I., 1998. Measuring feeding and absorption in suspensionfeeding bivalves : an appraisal of the biodeposition method. J. Exp. Mar. Biol. Ecol. 219, 71-86.

Jørgensen, C.B., 1990. Bivalve filter-feeding : hydrondynamics, bioenergetics, physiology and ecology. Olsen and Olsen (Ed.), Fredensborg (Denmark), 140 pp.

Leborgne, R., Blanchot, J., Charpy, L., 1989. Zooplankton of Tikehau atoll (Tuamotu archipelago) and its relationship to particulate matter. Mar. Biol. 102, 341-353.

Le Gall, S., Bel Hassen, M., Le Gall., P., 1997. Ingestion of a bacterivorous ciliate by the oyster Crassostrea gigas : protozoa as a trophic link between picoplankton and benthic suspension-feeders. Mar. Ecol. Prog. Ser. 152, 301-306.

Loret, P., 1998. Rôle des protistes dans la nutrition de l'huître perlière Pinctada margaritifera. Rapport PGRNII, Action de recherche $n^{\circ} 11$, EPHE Moorea, Polynésie Française, 38 pp.

Mann, R., 1979. Some biochemical and physiological aspects of growth and gametogenesis in Crassostrea gigas 
and Ostrea edulis grown at sustained elevated temperatures. J. Mar. Biol. Assoc. U.K. 59, 95-110.

Marshall, N., 1968. Observations on organic aggregates in the vicinity of coral reefs. Mar. Biol. 2, 50-53.

Méro, D., 1996. Contribution à l'étude de l'excrétion azotée de l'huître perlière Pinctada margaritifera. Rapport ISTOM, Cergy Pontoise (France), 45 pp.

Niquil, N., 1998. Etude par la modélisation du fonctionement et de la stabilité du réseau trophique planctonique d’un lagon d’atoll (Takapoto, Polynésie Française). Th. Univ. Perpignan (France), 190 pp.

Niquil, N., Jackson, G.A., Legendre, L., Delesalle, B., 1998. Inverse model analysis of the planktonic food web of Takapoto Atoll (French Polynesia). Mar. Ecol. Prog. Ser. 165, 17-29.

Parsons, T.R., Stephens, K., Strickland, J.D.H., 1961. On the chemical composition of eleven species of marine Phytoplankters. J. Fish. Res. Bd. Canada 18, 1001-1016.

Pouvreau, S., 1999. Etude et modélisation des mécanismes impliqués dans la croissance de l'huître perlière, Pinctada margaritifera, au sein de l'écosystème conchylicole de l'atoll de Takapoto (Polynésie Française). Th. ENSA, Rennes (France), 267 pp (+Annexes).

Pouvreau, S., Bodoy, A., Buestel, D., 1998. Détermination du bilan énergétique chez l’huître perlière, Pinctada margaritifera, et premier modèle écophysiologique de croissance dans le lagon d'atoll de Takapoto. Rapport IFREMER, Tahiti (French Polynesia), RI DRV 98-01, 69 pp.

Pouvreau, S., Jonquières, G., Buestel, D., 1999a. Filtration by the pearl oyster, Pinctada margaritifera, under conditions of low seston load and small particle size in tropical lagoon habitat. Aquaculture 176, 295-314.

Pouvreau S., Bodoy A., Buestel D., 1999b. In situ suspension feeding behaviour of the pearl oyster, Pinctada margaritifera : Combined effects of body size and weather-related seston composition. Aquaculture 181, 91113.

Pouvreau S., Tiapari J., Gangnery A., Lagarde F., Garnier M., Teisser H., Haumani G., Buestel D., Bodoy A., 2000. Growth of the black-lip pearl oyster, Pinctada margaritifera, in suspended culture under hydrobiological conditions of Takapoto lagoon (French Polynesia). Aquaculture, in press.

Powell, E.N., Hofmann, E.E., Klinck, J.M., Ray, S.M., 1992. Modeling oyster populations. I. A commentary on filtration rate. Is faster always better . J. Sea Res. 11, 387-398.

Prou, J., Bennett, A., Tiapari, J., Haumani, G. 1999. Estimation des stocks de nacres, Pinctada margaritifera, en élevage à Takapoto (Polynésie française). Rapport PGRN, Phase II, IFREMER-COP, Tahiti, 33 pp.

Quemeneur, M., Marty, Y., 1992. Sewage influence in a macrotidal in a macrotidal estuary : fatty acid and sterol distributions. Est. Coast. Shelf. Sci. 34, 347-363.

Raillard, O., Deslous-paoli, J.M., Héral, M., Razet, D., 1993. Modélisation du comportement nutritionnel et de la croissance de l’huître japonaise Crassostrea gigas. Oceanologica Acta 16 (1), 73-82.

Renon, J.P., 1977. Zooplancton du lagon de l'atoll de Takapoto (Polynésie française). Ann. Inst. océanogr. 53 (2), 217-236.

Robert, S., Pouvreau, S., Buestel, D., Goulletquer, P., Bennett, A., Caisey, X., Teissier, H., Jonquières, G., Tiapari, J., Haumani, G., 1998. Energy budget of the pearl oyster Pinctada margaritifera: in situ respiration rate assessment and allometry relationship with dry meat weight oyster. Aquaculture Europe 98, 7-10 Octobre 1998, Bordeaux (France). Abstract only.

Rodhouse, P.G., Roden, C.M., Burnell, G.M., Hensey, M.P., McMahon, T., Ottway, B., Ryan T.H., 1984. Food resource, gametogenesis and growth of Mytilus edulis on the shore and in suspended culture: Killary Harbour, Ireland. J. Mar. Biol. Assoc. U.K. 64, 513-529.

Ross, A.H., Nisbet R.M., 1990. Dynamic models of growth and reproduction of the mussel Mytilus edulis L. Funct. Ecol. 4, 777-787

Rougerie, F., 1979. L'environnement de l'Atoll de Takapoto-Tuamotu. Caractéristiques générales du milieu liquide 
lagonaire de l'atoll de Takapoto. J. Soc. Océanistes 33 (62), 35-45.

Schneider, D.W., 1992. A bioenergetics model of zebra mussel, Dreissena polymorpha, growth in the great lakes. Can. J. Fish. Aquat. Sci. 49, 1406-1416.

Scholten, H., Smaal, A.C., 1998. Responses of Mytilus edulis L. to varying food concentrations: testing EMMY, an ecophysiological model. J. Exp. Mar. Biol. Ecol. 219, 217-239.

Sournia, A., Ricard M., 1975. Phytoplankton and primary productivity in Takapoto atoll, Tuamotu Islands. Micronesia 11, 159-166.

Sournia, A., Ricard, M., 1976. Données sur l'hydrologie et la productivité du lagon d'un atoll fermé (Takapoto, Iles Tuamotu). Vie et milieu 26, 243-279.

Thielley, M., 1993. Etude cytologique de la gamétogenèse, de la sex-ratio et du cycle de reproduction chez l'huître perlière Pinctada margaritifera (L) var. cumingii (Jameson), (mollusques, bivalves). Comparaison avec le cycle de Pinctada maculata (Gould). Th. Univ. Tahiti (French Polynesia), 233 pp.

Thompson, R.J., 1984. Production, reproductive effort, reproductive value cost in a population of the blue mussel Mytilus edulis from a subarctic environment. Mar. Ecol. Prog. Ser. 16, 249-257.

Torréton J.P., Dufour P., 1996. Temporal and spatial stability of bacterioplankton biomass and productivity in an atoll lagoon. Aquat. Microb. Ecol. 11, 251-261.

Torréton J.P., Pagès J., Dufour P., Cauwet G., 1997. Bacterioplankton carbon growth yield and DOC turnover in some coral reef lagoons. Proc $8^{\text {th }}$ Int Symp Coral Reef, Panamà (Panama), pp 947-952.

Vacelet, E., Arnoux, A., Thomassin, B., 1996. Particulate material as an indicator of pearl-oyster excess in the Takapoto lagoon (Tuamotu, French Polynesia). Aquaculture 144, 133-148.

Van Haren, R.J.F., Kooijman, S.A.L.M., 1993. Application of a dynamic energy budget model to Mytilus edulis (L.). Neth. J. Sea Res. 31, 119-133.

Yukihira, H., Klumpp, D.W., Lucas, J.S., 1998a. Effects of body size on suspension feeding and energy budgets of the pearl oysters Pinctada margaritifera and P. maxima. Mar. Ecol. Prog. Ser. 170, 119-130.

Yukihira, H., Klumpp, D.W., Lucas, J.S. 1998b. Comparative effects of microalgal species and food concentration on suspension feeding and energy budgets of the pearl oysters Pinctada margaritifera and P. maxima (Bivalvia : Pteriidae). Mar. Ecol. Prog. Ser. 171, 71-84.

Yukihira, H., Klumpp, D.W., Lucas, J.S. 1999. Feeding adaptations of the pearl oysters Pinctada margaritifera and P. maxima to variations in natural particulates. Mar. Ecol. Prog. Ser. 182, 161-173.

Zanini, J.M., 1995. Méthode d'estimation du stock naturel de nacres - Pinctada margaritifera - de lagons d'atoll, à travers l'exemple des lagons de Marutea Sud et de Takapoto (Polynésie Française). Rapport EPHE-EVAAM. RA 65, Tahiti (French Polynesia), 40 pp. 
Table 1 : POC concentration ( $\mu \mathrm{gC} \mathrm{l}^{-1}$ ) for the main groups of the particulate organic matter in Polynesian atoll lagoons. Mean values were re-calculated from several works conducted, between 1975 and 1998, in mid-waters of Takapoto or Tikehau lagoon. Calculations were obtained by using the following conversion factor : C/Chl $a=50$ for phytoplankton (Charpy and Charpy-Roubaud, 1990); C/Chl $a=82$ for cyanobacteria (Charpy et al., 1992); POM to POC conversion factor $=0.5$. As authors have not used the same size-fractioning, some approximations have been made in the table. Global mean (+/- SE) and contribution of each group were computed on the basis of all these published values. Note that the total mean of POC is rather constant and independent of the study around $0.180 \mathrm{mg} \mathrm{C} \mathrm{l}^{-1}$, i.e. POM=0.40 $\mathrm{mg} \mathrm{l}^{-1}$, showing the strong stability of this parameter between years.

* References : 1. Sournia and Ricard (1975); 2. Sournia and Ricard (1976); 3. Renon (1977); 4. Blanchot et al. (1989); 5. Leborgne et al. (1989); 6. Charpy and Charpy-Roubaud (1990); 7. Charpy and Charpy-Roubaud (1991); 8. Charpy et al. (1992); 9. Charpy et al. (1994); 10. Vacelet et al. (1996); 11. Charpy (1996); 12. Torréton and Dufour (1996); 13. Torréton et al. (1997); 14. Charpy et al. (1997); 15. Charpy and Blanchot (1998); 16. Loret (1998); 17. Niquil (1998); 18. Pouvreau (1999); 19. This study.

\begin{tabular}{|c|c|c|c|c|c|c|c|c|c|c|c|c|c|c|c|c|c|c|c|}
\hline \multirow{2}{*}{\multicolumn{2}{|c|}{$\begin{array}{l}\text { Size and taxonomic } \\
\text { composition }\end{array}$}} & \multicolumn{16}{|c|}{ References* } & \multirow{2}{*}{$\begin{array}{l}\text { Global mean } \\
\qquad(+/-\mathrm{SE})\end{array}$} & \multirow{2}{*}{$\begin{array}{l}\% \text { of the } \\
\text { total POC }\end{array}$} \\
\hline & & 1 & 2 & 3 & 4 & 5 & 6 & 7 & 8 & 9 & 10 & 111213 & 14 & 15 & 16 & 17 & $18 \quad 19$ & & \\
\hline \multirow{4}{*}{$\underset{\mathrm{V}}{\underline{\underline{Z}}}$} & Bacteria & & & & 17 & & 17 & & & 16 & 3 & 2313 & & & & 15 & & $15+/-2$ & $8 \%$ \\
\hline & Cyanobacteria & & & & 10 & & & & 16 & 7 & & 13 & & 13 & & 16 & & $12+/-1$ & $7 \%$ \\
\hline & Picoeukaryotes & & & & 2 & & 3 & & & 6 & & 4 & & 13 & & 63 & & $15+/-10$ & $8 \%$ \\
\hline & PicoDetritus & & & & 118 & & 82 & & & 60 & & & & & & 50 & & $78+/-15$ & $41 \%$ \\
\hline \multirow{5}{*}{$\underset{\wedge}{\underline{\Xi}}$} & Phytoplankton & & & & 1 & & 6 & & & 5 & 4 & 3 & & & 8 & 50 & & $11+/-7$ & $6 \%$ \\
\hline & Protozoa & & & & 3 & & 2 & & & $\mathbf{0}$ & & & & & 10 & 31 & & $9+/-6$ & $5 \%$ \\
\hline & Zooplankton & & & 4 & 3 & 7 & 2 & & & 4 & & & & & & 2 & & $4+/-1$ & $2 \%$ \\
\hline & Micro-Detritus & & & & 34 & & 84 & & & 38 & & & & & & 23 & & $45+/-14$ & $24 \%$ \\
\hline & $250 \mu \mathrm{m}>$ POC $>2 \mu \mathrm{m}$ & & & & 41 & & 94 & & & 47 & & & 35 & & & 106 & & $68+/-15$ & $36 \%$ \\
\hline \multirow{4}{*}{$\underset{⿱ 乛}{\infty}$} & Living POC & & & & 36 & & 29 & & & 37 & & & & & & 176 & & $66+/-36$ & $35 \%$ \\
\hline & Autotrophic POC & 6 & 28 & & 13 & & 9 & & & 18 & & 20 & 16 & & & 129 & 20 & $38+/-13$ & $20 \%$ \\
\hline & Heterotrophic POC & & & & 23 & & 20 & & & 20 & & & & & & 48 & & $27+/-7$ & $15 \%$ \\
\hline & Total POC & & 160 & & 188 & & 196 & 192 & & 135 & 180 & & 115 & & & 249 & 175195 & $188+/-12$ & \\
\hline
\end{tabular}


Table 2: Model variables and values of the coefficients used in the growth model. * References : 1. Pouvreau et al. (1999b); 2. Dufour and Torréton (1996); 3. Pouvreau et al. (1999a); 4. Loret (1998); 5. Pouvreau et al. (1998); 6. Robert et al. (1998); 7. This study; 8: Pouvreau (1999).

\begin{tabular}{|c|c|c|c|}
\hline Acronym & Value & Unit & References \\
\hline \multicolumn{4}{|c|}{ STATES VARIABLES } \\
\hline SHELL & f(TIME) & g & Biomass of shell \\
\hline SOMA & f(TIME) & g & Biomass of soma \\
\hline GONAD & f(TIME) & $\mathrm{g}$ & Biomass of gonad \\
\hline \multicolumn{4}{|c|}{ FORCING VARIABLES } \\
\hline POM & f(TIME) & $\mathrm{mg} \mathrm{l}^{-1}$ & Particulate organic matter in suspension \\
\hline PIM & f(TIME) & $\mathrm{mg} \mathrm{l}^{-1}$ & Particulate inorganic matter in suspension \\
\hline $\mathrm{POC}_{\mathrm{i}}$ & f(TIME) & $\mathrm{mgC} \mathrm{l}^{-1}$ & Carbon concentration in each POM-group i \\
\hline
\end{tabular}

Clearance Rate : CR = aCR $\times$ PIM $^{b_{C R}} \times$ POM $^{C^{C R}} \times$ W $^{d_{C R}}$

\begin{tabular}{lccl|l}
\hline aCR & 647.04 & $\mathrm{Id}^{-1} \mathrm{~g}^{-1}$ & Proportionality coefficient & \\
$\mathrm{bCR}$ & -0.42 & - & PIM-exponent coefficient & $\mathbf{1}$ \\
$\mathrm{CCR}$ & 0.96 & - & POM-exponent coefficient & \\
$\mathrm{d}_{\mathrm{CR}}$ & 0.61 & - & W-exponent coefficient &
\end{tabular}

Consumption Rate : FRPom $=$ CR $x$ Sum $\left(\right.$ aRE $\left./ 100 \times P^{2} C_{i}\right)$

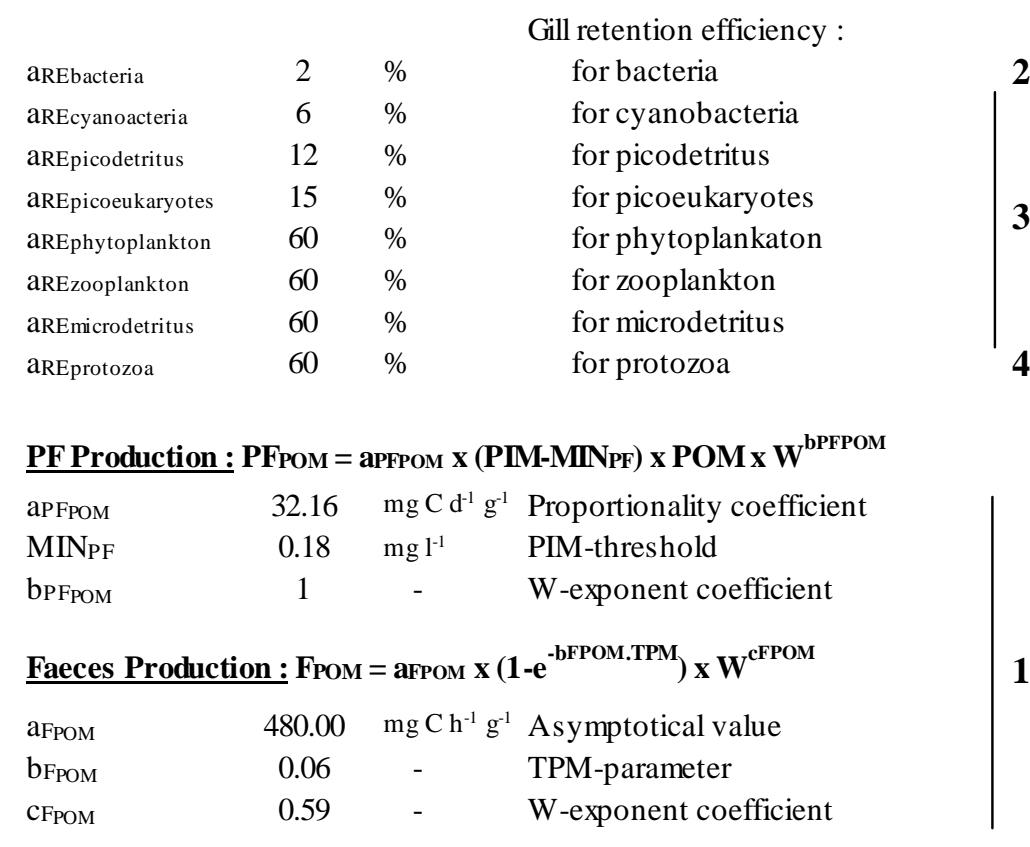

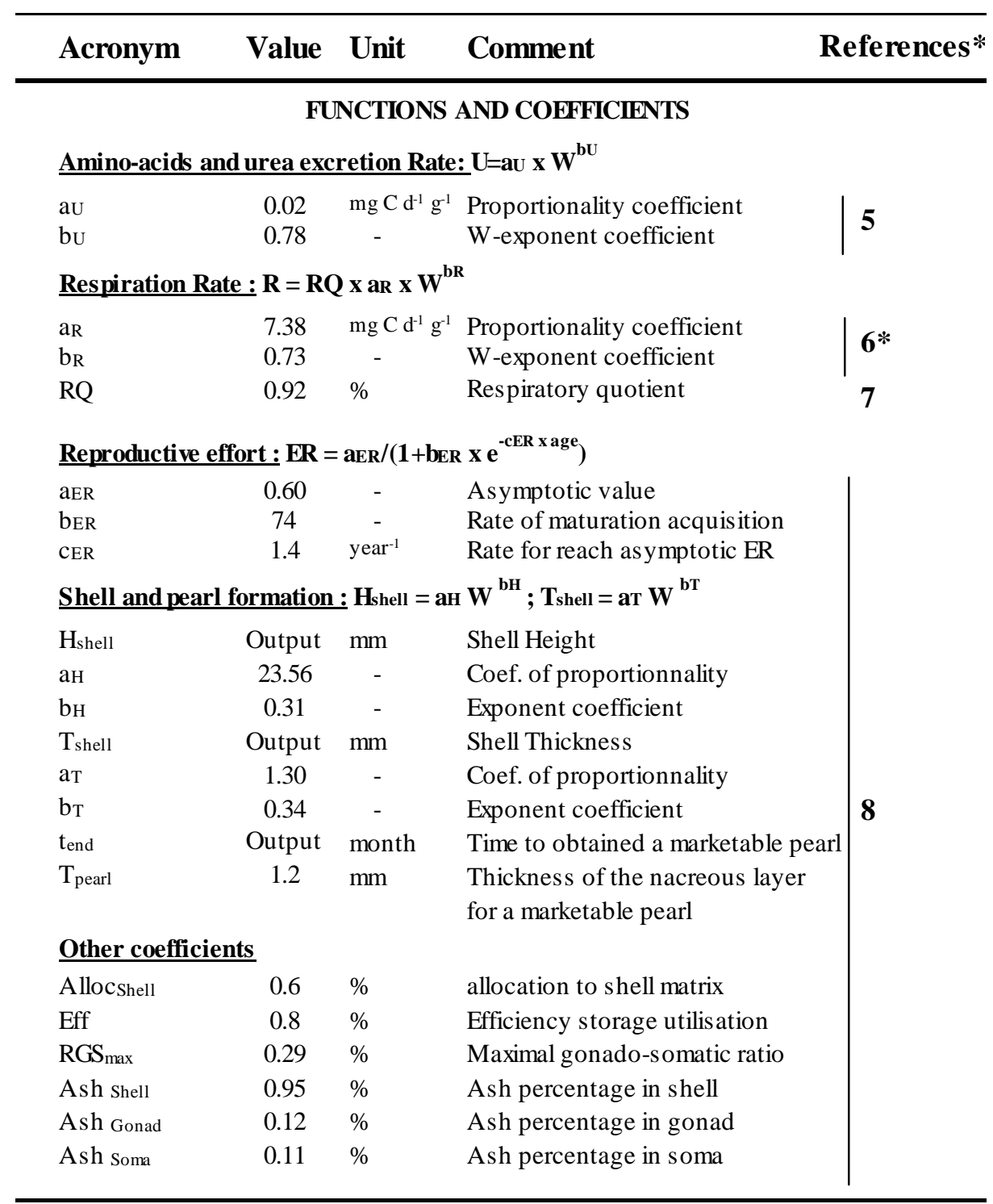

* Converted using $1 \mathrm{mg} \mathrm{O} 2=0.696 \mathrm{ml} \mathrm{O}_{2}$ and $1 \mathrm{ml} \mathrm{CO} 2=0.53 \mathrm{mg} \mathrm{C}$ 
Table 3 : Model equations

SCOPE FOR GROWTH $\left(\mathrm{mgC} \mathrm{d}^{-1}\right)$ :

$\mathrm{SFG}=\mathrm{FR}_{\mathrm{POM}}-\left(\mathrm{PF}_{\mathrm{POM}}+\mathrm{F}_{\mathrm{POM}}+\mathrm{U}+\mathrm{R}\right)$

CARBON ALLOCATION (mgC $\left.\mathbf{~ d}^{-1}\right)$ :

If $S F G>0: \quad$ ToGONAD $=$ ER・SFG

ToSOMA $=(1$-ER $) \cdot\left(1-\right.$ Alloc $\left._{\text {shell }}\right) \cdot$ SFG

ToSHELL $=(1-\mathrm{ER}) \cdot\left(\right.$ Alloc $\left._{\text {shell }}\right) \cdot \mathrm{SFG}$

If $S F G<0: \quad$ ToGONAD $=\mathrm{SFG}+(1-\mathrm{Eff}) \cdot \mathrm{SFG}$

If $\mathrm{GONAD}=0$ then ToSOMA $=\mathrm{SFG}+(1-\mathrm{Eff}) \cdot \mathrm{SFG}$ TOSHELL $=0$

SPAWNING (mgC) :

If $R G S>R G S_{\max } \quad$ SPAWNING $=$ GONAD

DIFFERENTIAL EQUATIONS :

dGONAD/dt $=$ ToGONAD

$\mathrm{dSHELL} / \mathrm{dt}=$ ToSHELL

$\mathrm{dSOMA} / \mathrm{dt}=$ ToSOMA

WEIGHT (g):

$\mathrm{W}_{\text {Tissue }}=\mathrm{SOMA} /\left(1-\mathrm{Ash}_{\text {Tissue }}\right)+\mathrm{GONAD} /\left(1-\mathrm{Ash}_{\mathrm{Gonad}}\right)$

$\mathrm{W}_{\mathrm{Gonad}}=\mathrm{GONAD} /\left(1-\mathrm{Ash}_{\mathrm{Gonad}}\right)+\mathrm{DG} \cdot \mathrm{SOMA} /\left(1-\mathrm{Ash}_{\text {Tissue }}\right)$

$\mathrm{W}_{\text {Shell }}=\mathrm{SHELL} /\left(1-\right.$ Ash $\left._{\text {Gonad }}\right)$

$\mathrm{DG}=$ Fraction in weight of the digestive gland in the total tissue weight 
Table 4 : Date and intensity (Pr, mg) of the gametes release given by the model according to the age and to the dry tissue weight ( $\mathrm{W}_{\text {Tissue }}$ ) of pearl oyster in the 1997-98 period in Takapoto lagoon.

\begin{tabular}{cccc}
\hline Age-group & $\begin{array}{c}\text { Date of } \\
\text { spawning }\end{array}$ & Pr (mg) & W (g) \\
\hline 1 & $07 / 01 / 98$ & 172 & 2.2 \\
2 & $20 / 10 / 97$ & 453 & 5.1 \\
& $30 / 12 / 97$ & 545 & 6.2 \\
3 & $10 / 05 / 97$ & 545 & 6.5 \\
& $02 / 10 / 97$ & 629 & 7.4 \\
& $29 / 11 / 97$ & 671 & 7.8 \\
& $27 / 12 / 97$ & 705 & 8.2 \\
\hline
\end{tabular}


Table 5 : Clearance time (days) for each population of suspension-feeding bivalves encountered in the Takapoto lagoon. Specific comments : (1) Gaby Haumani (pers. comm.); (2) Assuming a ratio 1/10 between pearl oysters on spat collectors and P. maculata; (3) Zanini (1995); (4) Addessi (1997a); (5) Calculated using retention efficiency spectrum of bivalves and taxonomic composition of POC.

\begin{tabular}{|c|c|c|c|c|c|c|}
\hline & Population of bivalves & $\begin{array}{l}\text { Stocks } \\
\text { (10 }{ }^{6} \text { ind.) }\end{array}$ & $\begin{array}{c}\text { Individual } \\
\text { Consumption } \\
\left(\mathrm{mg} \mathrm{C} \mathrm{d}^{-1} \text { ind }^{-1}\right)\end{array}$ & $\begin{array}{c}\text { Total } \\
\text { Consumption } \\
\left(\mathrm{mT} \mathrm{C} \mathrm{d}^{-1}\right)\end{array}$ & $\begin{array}{c}\text { POC available } \\
\text { for bivalves } \\
\text { (mT C) }\end{array}$ & $\begin{array}{c}\text { Clearance } \\
\text { Time } \\
\text { (days) }\end{array}$ \\
\hline \multirow{3}{*}{ 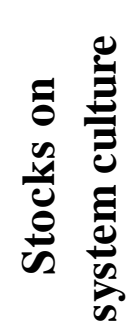 } & Cultivated pearl oyster & $2^{(1)}$ & & 0.07 & 135 & 1880 \\
\hline & $\begin{array}{c}\text { Class I } \\
\text { Class II } \\
\text { Class III }\end{array}$ & $\begin{array}{l}0.9 \\
0.4 \\
0.4\end{array}$ & $\begin{array}{l}20 \\
60 \\
75\end{array}$ & $\begin{array}{l}0.02 \\
0.02 \\
0.03\end{array}$ & & \\
\hline & $\begin{array}{r}\text { Associated trophic } \\
\text { competitors }\end{array}$ & $10^{(2)}$ & 13 & 0.13 & 135 & 1041 \\
\hline \multirow{5}{*}{ 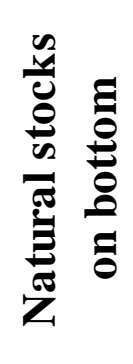 } & Natural pearl oyster & $4^{(3)}$ & 42 & 0.17 & 135 & 810 \\
\hline & $\begin{array}{r}\text { Trophic competitors } \\
\text { Arca ventricosa }\end{array}$ & $635^{(4)}$ & 32 & 20.2 & 135 & 7 \\
\hline & Pinctada maculata & $31^{(4)}$ & $\begin{array}{l}32 \\
13\end{array}$ & $\begin{array}{c}20.2 \\
0.4\end{array}$ & $\begin{array}{l}135 \\
135\end{array}$ & 347 \\
\hline & Chama iostoma & $53^{(4)}$ & 26 & 1.4 & 135 & 97 \\
\hline & Total & & & 22.4 & 135 & 6 \\
\hline
\end{tabular}




\section{FIGURES}

Fig. 1 : Schematic of the conceptual pearl oyster growth model.
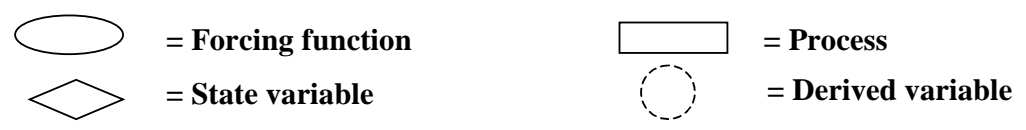

Fig. 2 : Annual evolution of forcing function (daily mean value for PIM and POM, mg $\mathrm{l}^{-1}$, +/- SE) during 1997-98 in station 1 of Takapoto lagoon.

Fig. 3 : Long lines systems and principle of food depletion.

Fig. 4 : Results of simulated (thick line) and measured ( $\square$ ) individual growth of Pinctada margaritifera during 1997-98 in the three age-groups in station 1 in Takapoto lagoon. a : Growth in shell (dry weight, $\mathrm{W}_{\text {Shell }}, \mathrm{g}$ ) ; b : Growth in total tissue (dry weight, $\mathrm{W}_{\text {Tissue, }}, \mathrm{g}$ ) ; c : Growth in gonadic tissue (dry weight, $\mathrm{W}_{\text {Gonad }}, \mathrm{g}$ ). Arrows indicate spawning events. Plots $\mathrm{d}$, e and $\mathrm{f}$ describes predicted value (Y-axis) vs observed data (X-axis) for each of the state variables of the growth model.

Fig. 5 : Annual variations of the main feeding processes and the scope for growth of Pinctada margaritifera for each of the three age-groups of pearl oysters (age-group 1 : thick line ; age-group 2 : normal line ; agegroup 3 : fine line). $\mathrm{CR}=$ clearance rate, $\mathrm{FR}_{\mathrm{POM}}=$ Organic consumption rate, $\mathrm{PF}_{\mathrm{POM}}$ and $\mathrm{F}_{\mathrm{POM}}=$ Biodeposition rates, $A_{b} R=$ Absorption rate $\left(A_{b} R=F R_{P O M}-P F_{P O M}-F_{P O M}\right)$ and $S F G=$ Scope for growth.

Fig. 6 : Simulated annual evolution of the rate of nacreous deposition and the daily increment in shell height $\left(\mu \mathrm{m} \mathrm{d}^{-1}\right.$ ind $\left.^{-1}\right)$ in the three age-groups of pearl oysters.

Fig. 7 : a : Effect of 1-year-POM depletion on final weight of shell, tissue and gonad for an age-group 3 pearl oyster; b : Effect of 1-year-POM depletion on the time necessary to achieve a pearl ( $\mathrm{t}_{\mathrm{End}}, \square$ ) and on the number of gametes releases ( $\mathrm{n}_{\text {gametes }}$ ) in one year $(\boldsymbol{\Delta})$ for an age-group 3 pearl oyster.

Fig. 8 : POM depletion (value in \%) according to the number of successive long-lines, the flow velocity and the linear density in each line. Areas in grey and black represent conditions for which POM depletion is assumed to have negative effects on growth, reproduction and pearl formation.

Fig. 9 : Conceptual design of the trophic relationship in the pelagic web around cultivated pearl oysters. Biomass are expressed in metric ton of carbon for the whole lagoon (TC), Fluxes (gross primary production, gPP, and bivalve filtration rate, FR) are expressed in $\mathrm{TC}^{-1}$. 


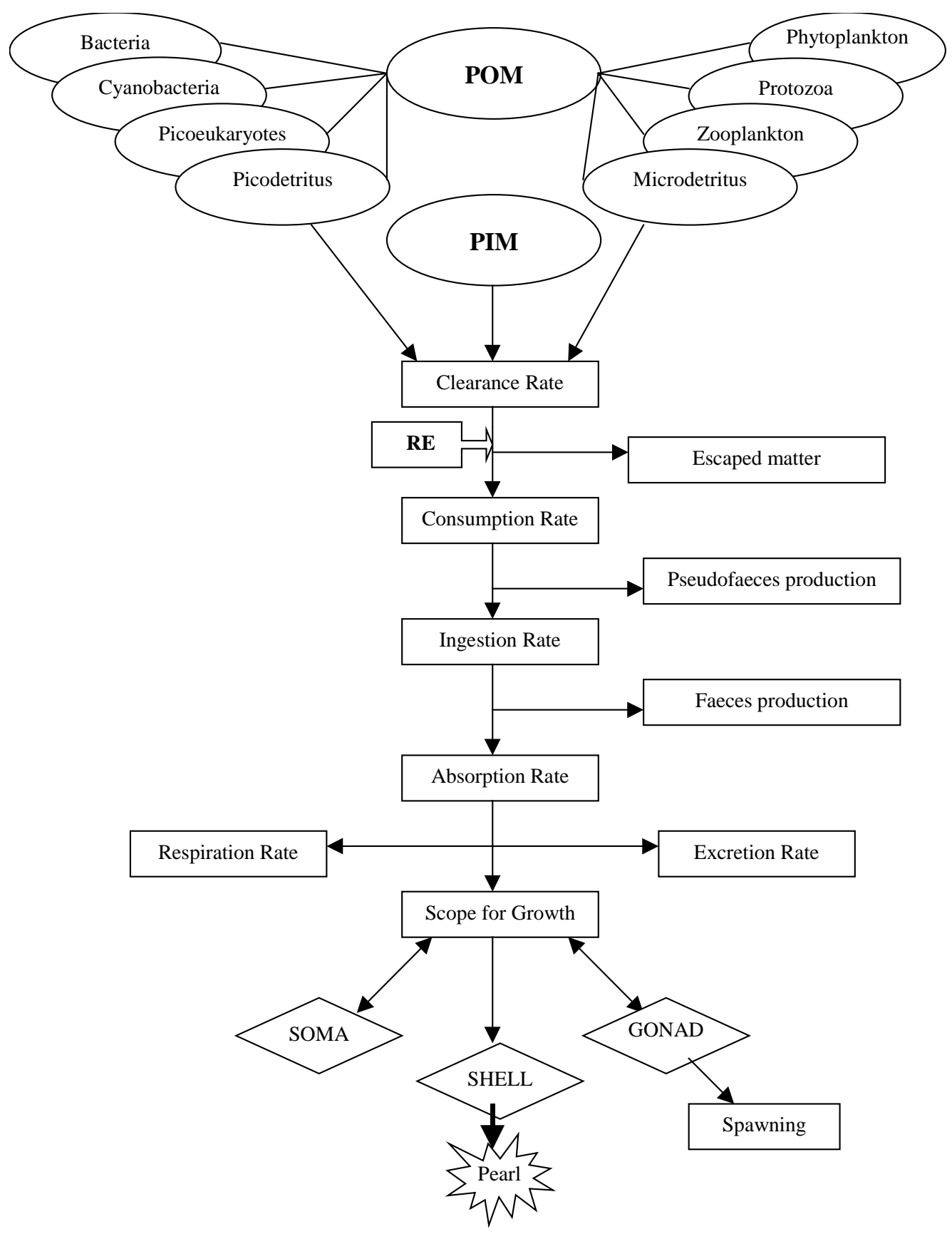

Figure 1 


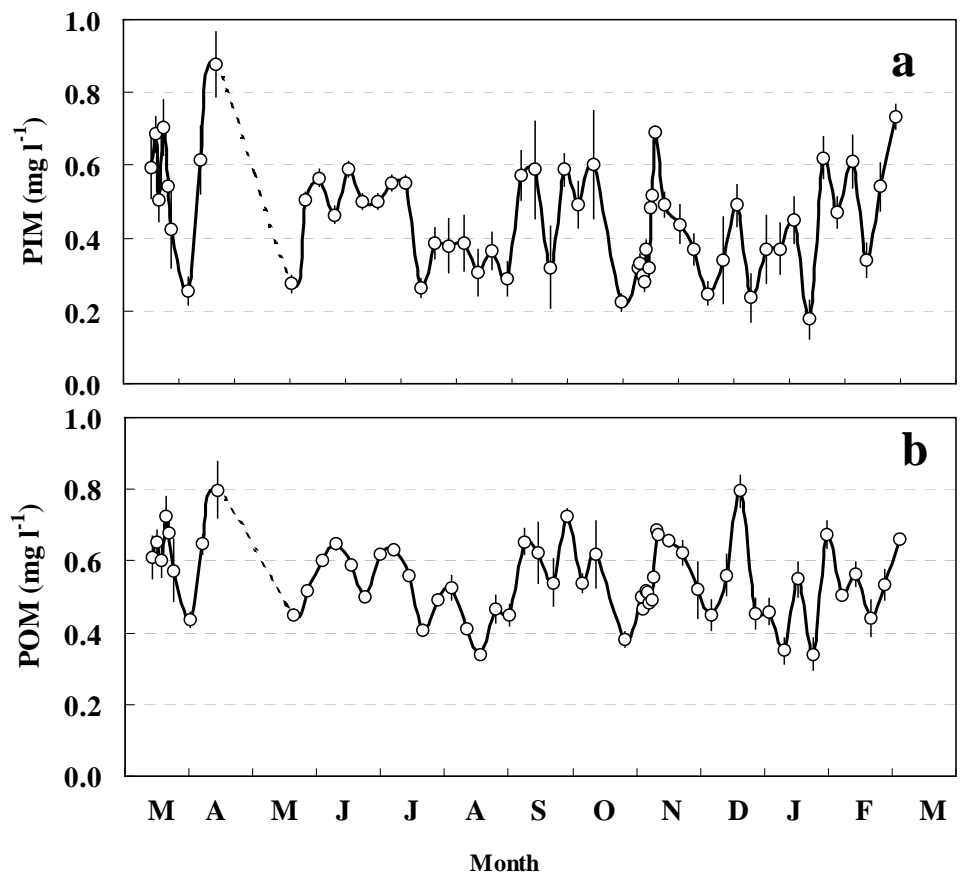

Figure 2 


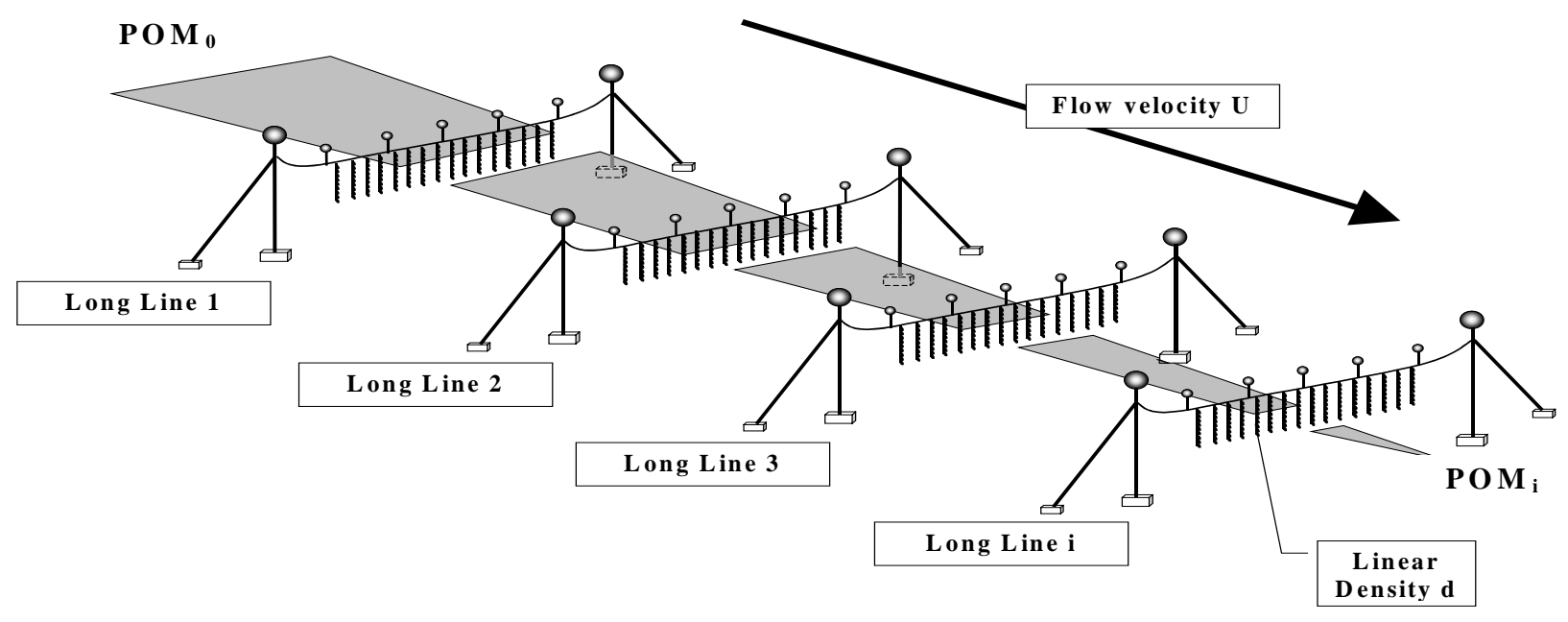

Figure 3 

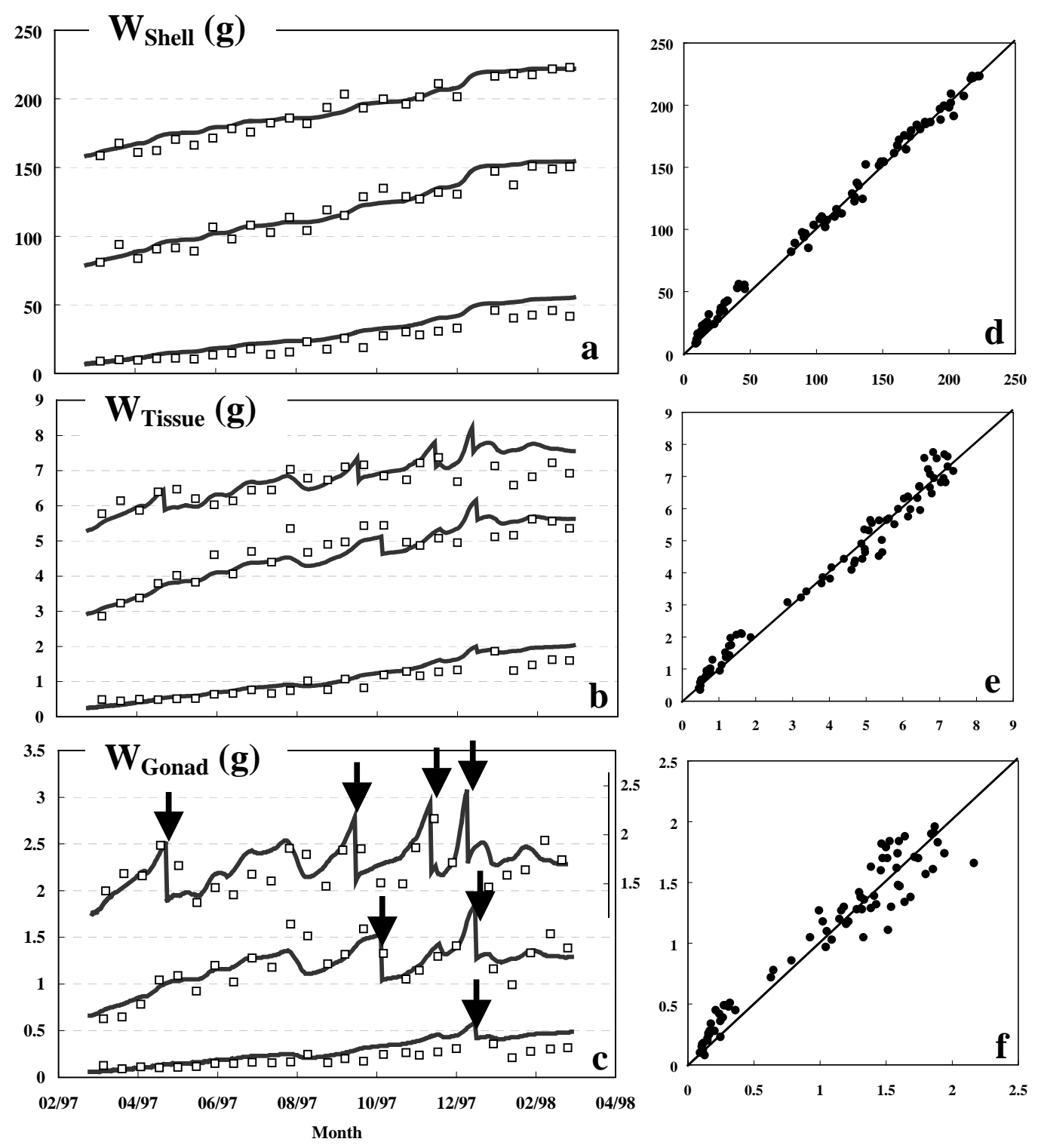

Figure 4 

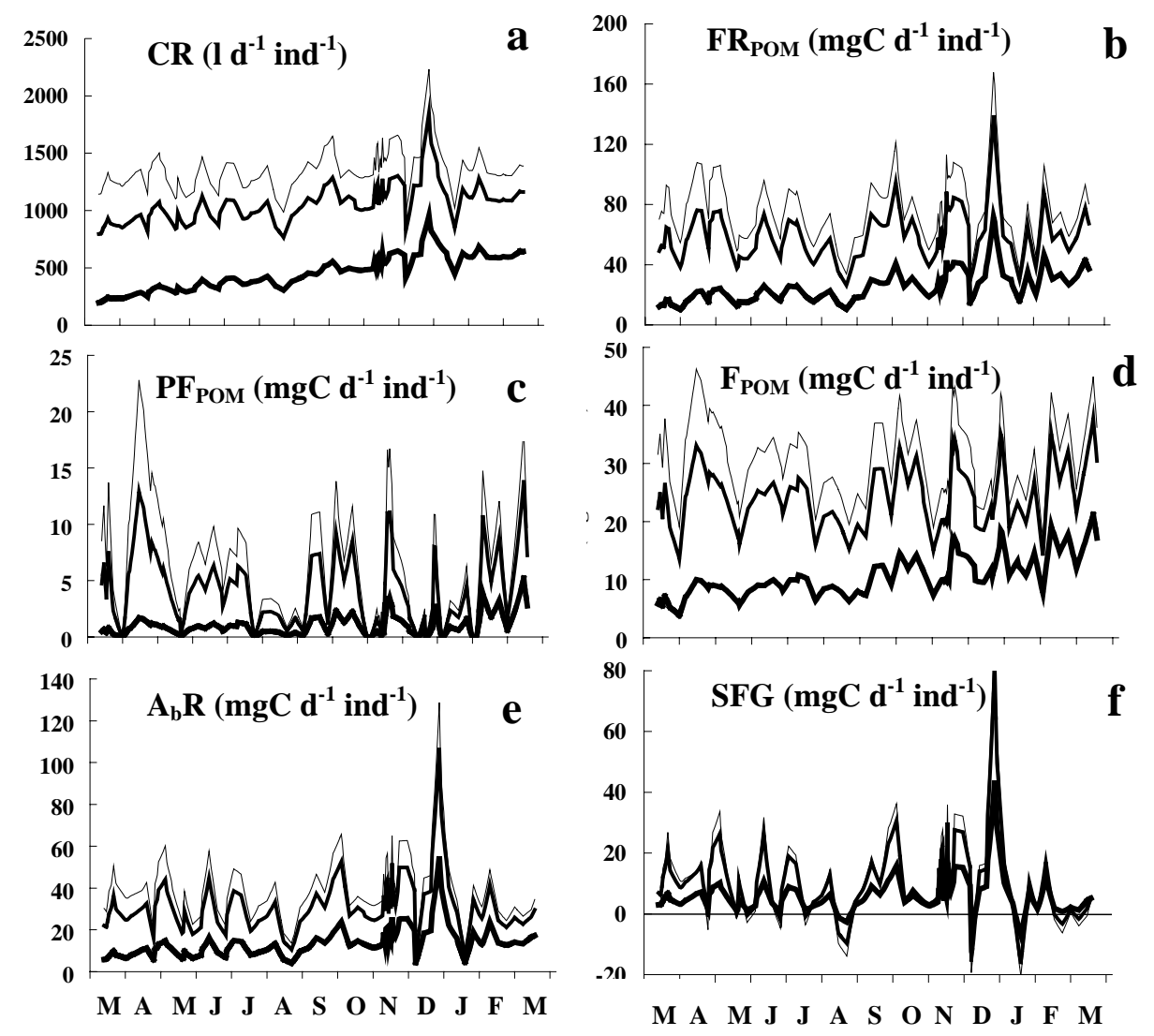

Figure 5 


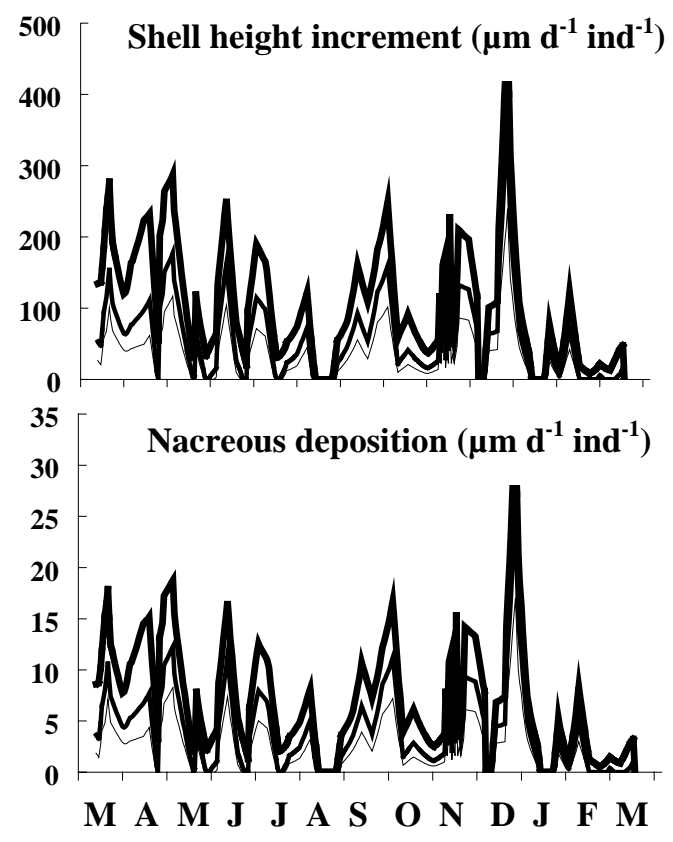

Figure 6 


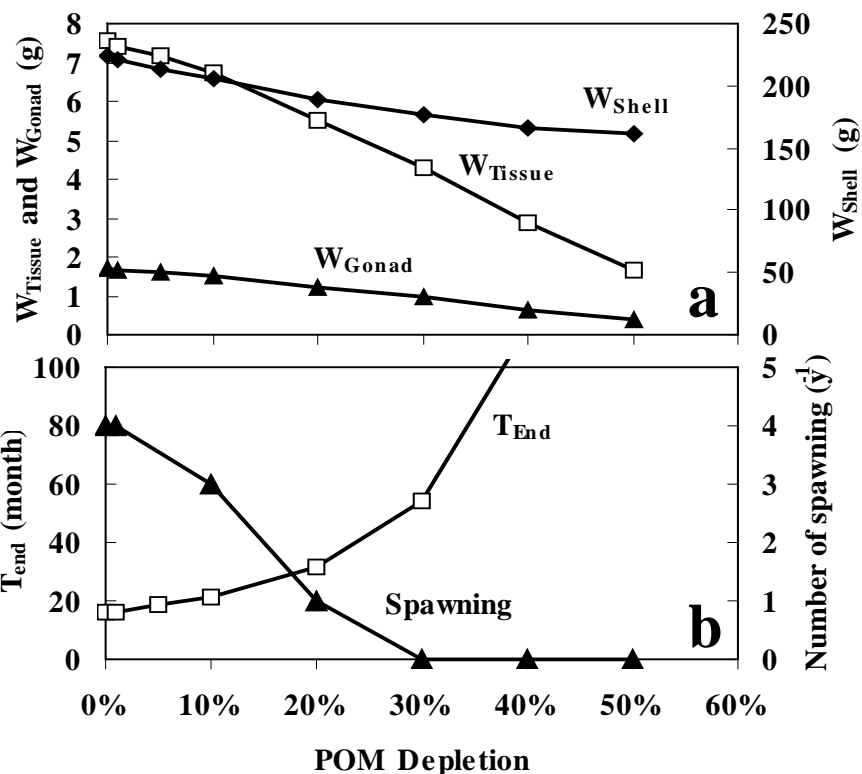

Figure 7 


\section{Linear density}
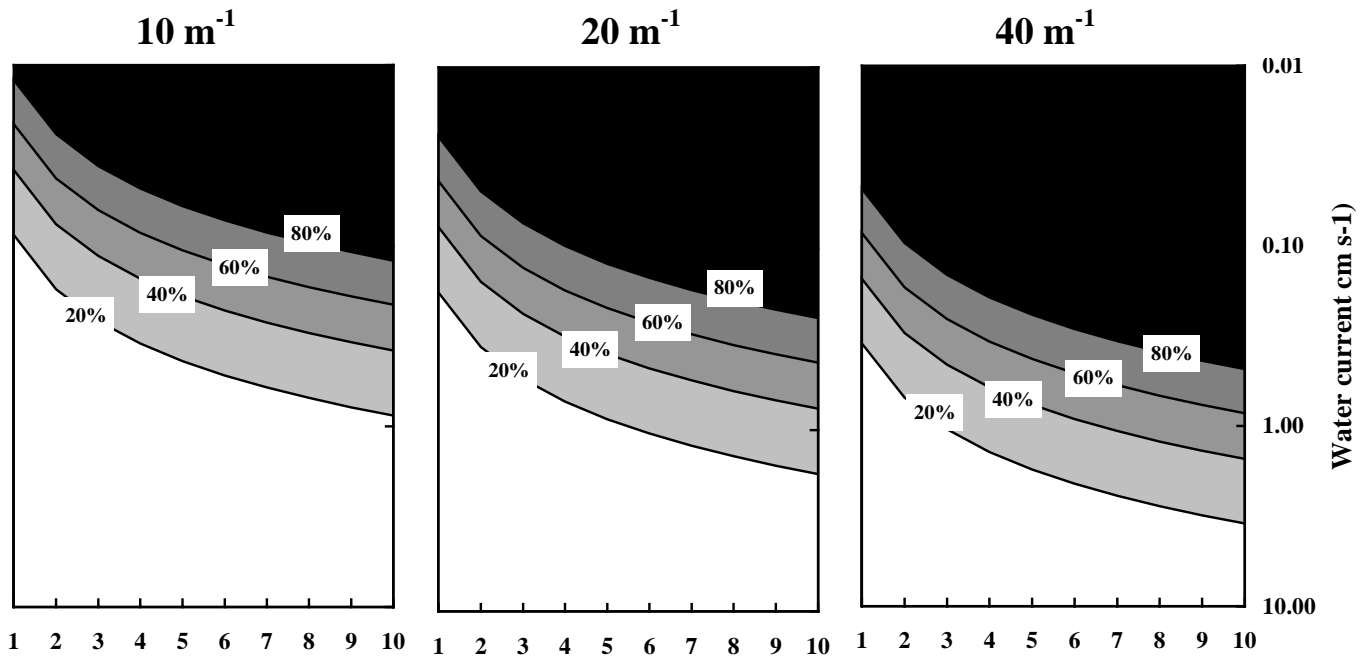

Long-lines number

Figure 8 


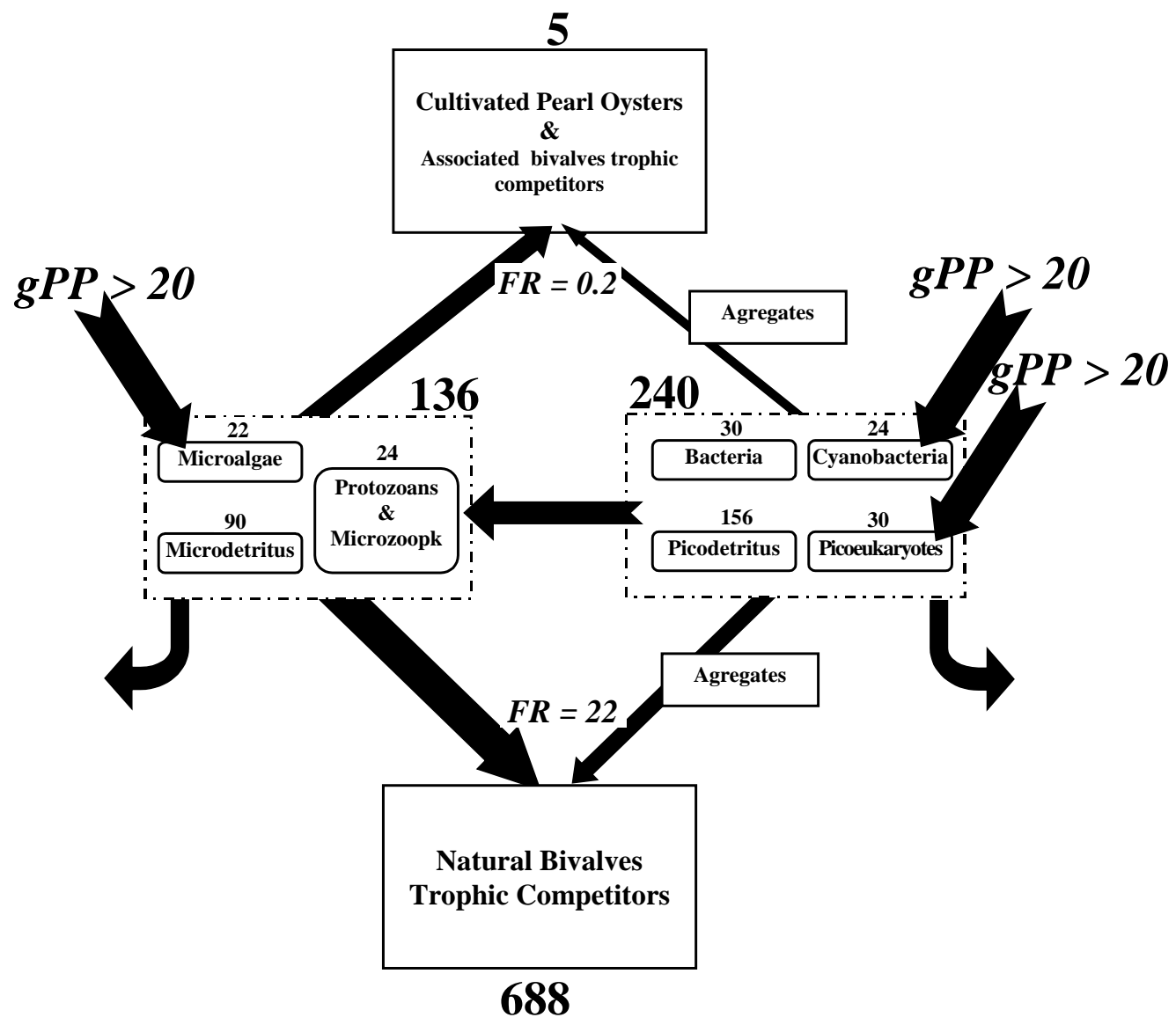

Figure 9 